SŁAWOMIR DOROCKI

Uniwersytet Pedagogiczny, Kraków

JAN PAWEŁ JASTRZĘBSKI

Uniwersytet Warmińsko-Mazurski, Olsztyn

\title{
Regionalne zróżnicowanie rozwoju biotechnologii w Europie
}

Przemysł biotechnologiczny jest współcześnie porównywany do technologii informatycznej, która jeszcze kilkadziesiąt lat temu stanowiła najbardziej innowacyjny i dochodowy sektor gospodarki. Dziś po okresie boomu na rozwój IT, biotechnologia postrzegana jest jako najważniejszy i najszybciej rozwijający się sektor gospodarki wysokich technologii (Kelly 2004). W ujęciu tym podkreśla się jej podstawowe cechy, jakimi są: innowacyjność, wszechstronny zakres zastosowań, czy generowanie postępu innych nauk podstawowych. Rosnąca rola biotechnologii związana jest również ze wzrostem liczby ludności i możliwym kryzysem żywnościowym w regionach słabo rozwiniętych gospodarczo, procesem starzenia się społeczeństw w krajach rozwiniętych i ich oczekiwaniami co do poprawy jakości życia oraz jej przyjazności względem środowiska (np. zmniejszenie zużycia chemicznych środków ochrony roślin).

Pierwszy raz termin ,biotechnologia” został użyty w 1919 roku przez węgierskiego agronoma Karla Ereky'ego w odniesieniu do produkcji rolniczej. Obecnie biotechnologia ma wiele definicji. Jedną z najszerszych podaje konwencja o różnorodności biologicznej ONZ. Określa ona, że biotechnologia oznacza zastosowanie procesów technologicznych, które wykorzystując organizmy żywe lub ich składniki, wytwarzają lub modyfikują produkty w określonym zastosowaniu. Biotechnologia jest zatem interdyscyplinarną nauką, integrująca ze sobą nauki przyrodnicze i technologiczne. Stanowi zatem pewien rodzaj technologii prowadzenia procesów oraz wytwarzania lub przetwarzania surowców biologicznych. Definicja opracowana przez Europejską Federację Biotechnologów głosi, że biotechnologia to integracja nauk przyrodniczych i inżynieryjnych w celu zastosowania komórek lub ich części oraz molekularnych analogów w celu pozyskania produktów i usług.

Historycznie biotechnologia obejmowała sposoby przeróbki lub konserwacji produktów pochodzenia roślinnego i zwierzęcego, jak na przykład kiszenie warzyw i owoców, czy produkcja napojów alkoholowych. Obecnie przy użyciu mikroorganizmów (bakterie i niższe grzyby) produkowane są m.in. antybiotyki, witaminy, enzymy, alkaloidy. Zastosowanie hodowli komórek zwierzęcych i roślinnych in vitro pozwoliło na produkcję czynników immunologicznych (szczepionki, interferony, interleukiny), hormonów, insektycydów oraz wielu 
innych cennych substancji. W ostatnim ćwierćwieczu gwałtowny rozwój biologii molekularnej związany z rozwojem metod inżynierii genetycznej umożliwił kontrolowaną ingerencję w zapis cech genetycznych organizmów, co pozwala na ulepszanie ich zdolności produkcyjnych. Zastosowanie biotechnologii np. w przemyśle spożywczym umożliwia przetwarzanie, wzbogacanie, utrwalanie, a także wytwarzanie żywności (Chmiel 1991).

Biotechnologię dzieli się na biotechnologię tradycyjną, w której stosuje się naturalne enzymy lub organizmy nie zawierające obcego materiału genetycznego oraz biotechnologię nowoczesną, stosującą zmodyfikowane genetycznie organizmy, enzymy i białka. Inny podział obejmuje biotechnologię zwierząt, roślin i żywności.

Stowarzyszenie EuropaBio (Europabi 2011), w którego skład wchodzą dwadzieścia cztery biotechnologiczne organizacje narodowe, zaproponowało podział biotechnologii na: białą (biotechnologia przemysłowa wykorzystująca systemy biologiczne w produkcji przemysłowej i ochronie środowiska), czerwoną (biotechnologia wykorzystywana w ochronie zdrowia, w szczególności w zakresie produkcji nowych biofarmaceutyków, rozwoju diagnostyki genetycznej, czy genoterapii i ksenotransplantologii), zieloną (biotechnologia związana $\mathrm{z}$ rolnictwem obejmująca stosowanie metod inżynierii genetycznej w celu doskonalenia produkcji roślinnej czy zwierzęcej) oraz fioletową (związana z ustawodawstwem, które dotyczy biotechnologii).

Przemysłowe procesy biotechnologiczne rozwijają się bardzo dynamicznie i z powodzeniem konkurują z metodami tradycyjnymi. Na świecie stosuje się je na szeroką skalę w takich dziedzinach, jak: przemysł chemiczny, farmaceutyczny, celulozowo-papierniczy, tekstylny, garbarski, spożywczy czy energetyczny. Przemysł biotechnologiczny zajmuje się przede wszystkim: produkcją kultur starterowych w przemyśle spożywczym, produkcją organizmów zmodyfikowanych genetycznie (GMO), sektorem farmaceutycznym (produkcja nowych leków, szczepionek, środków diagnostycznych), sektorem detergentów i bioremediacji (oczyszczanie ścieków), biotechnologią w rolnictwie do celów niespożywczych i w leśnictwie.

Przemysł biotechnologiczny w Europie Zachodniej zaczął się rozwijać w dużych przedsiębiorstwach w latach 80 . XX wieku. Natomiast w USA, główną siłą napędową przemysłu biotechnologicznego były małe przedsiębiorstwa. Europa zaczęła intensywnie rozwijać sektor biotechnologiczny pod koniec lat dziewięćdziesiątych ubiegłego wieku, kiedy to pojawiła się duża liczba małych i średnich przedsiębiorstw (MSP). Już w 2001 r. liczba europejskich MSP w sektorze biotechnologicznym była większa (ok. 1570) od tych funkcjonujących w USA (ok. 1273) (Life sciences and biotechnology 2002). Natomiast w 2004 roku w Europie były 2163 przedsiębiorstwa biotechnologiczne, przy $1991 \mathrm{w}$ USA, lecz europejskie firmy w większości były mniejsze niż amerykańskie (Biotechnology in Europe 2006). Oczywiście europejski przemysł biotechnologii wciąż pozostaje w tyle do transatlantyckich gigantów. Amerykański przemysł ustabilizował się na poziomie około 1400 korporacji biotechnologicznych i znajduje się aktualnie w fazie ekspansji, o czym świadczy trzykrotny, w porównaniu z przemysłem europejskim, zwrot nakładów oraz większa liczba zatrudnionych.

O szybkim rozwoju sektora biotechnologicznego mogą świadczyć wskaźniki finansowe. Według analityków finansowych inwestycje w sektor biotechnologiczny uznane zostały za jedne z najbardziej dochodowych inwestycji. Przykładem może być wzrost o przeszło $700 \%$ wypłacanej dywidendy dla akcjonariuszy jednej z największych amerykańskich firm biotechnologicznych Amgen ${ }^{1}$ (Shachmurove 2004). Ze względu na duże ryzyko inwestycyj-

1 Dawna Abgenix (przyp. autora). 
ne firmy biotechnologiczne (obok oprogramowania i telekomunikacji) mają najwięcej ofert na rynku Venture Capital. W USA oferty firm biotechnologicznych stanowią ok $40 \%$ firm z sektora Medical, Health and Life Science Industries (MHLS), a dodatkowo około 100 firm z sektora IT zalicza się do firm bioinformatycznych (Shachmurove, Shachmurove 2004).

Inną ważną cechą jest innowacyjność i szybki rozwój sektora biotechnologicznego. Wpływa to na duże ryzyko inwestycji w sektorze biotechnologicznym i wymusza lokalizację firm biotechnologicznych w przestrzennej bliskości ośrodków badań oraz infrastruktury i technologicznego know-how (Zucker i in. 1989; Stuart, Sorenson 2003). Rozwój firm biotechnologicznych następuje zatem głównie w bliskości światowej klasy uczelni wyższych, zapewniających dostęp do wysoko wykwalifikowanej siły roboczej i infrastruktury badawczej np. specjalistycznych laboratoriów, które w przypadku biotechnologii są często podstawą do prowadzenia badań naukowych (Autant-Bernard i in. 2010). Dodatkowo uznaje się, że transfer wiedzy jest ograniczony geograficznie. Dlatego dla firm kluczowe jest znaleźć się w bliskim sąsiedztwie źródła innowacji (Audretsch 2007; Barker i in. 2007). O silnym związku ośrodków naukowych i przemysłu biotechnologicznego może świadczyć fakt, że w Niemczech, kraju, który jest europejskim gigantem w sektorze biotechnologii, około $75 \%$ firm biotechnologicznych powstało na bazie finansowanych publicznie projektów badawczych. Także około $60 \%$ patentów biotechnologicznych zostało opatentowanych przez uczelnię (Wolf $\mathrm{i}$ in. 2010).

Można zatem uznać, że rozwój firm biotechnologicznych zależy w dużej mierze od zdolności do zatrudniania wysoko wykwalifikowanych i doświadczonych pracowników (Stuart, Sorenson 2003; Borowiec 2008). Uznaje się, że w przypadku kapitału ludzkiego w sektorze biotechnologii przepływ wiedzy, pomimo wydawałoby się dużej mobilności zawodowej, jest jednak ograniczony do przestrzennie skoncentrowanego rynku pracy (tacit knowledge) (Saxenian 1999, 2003; Dahl, Sorenson 2007). Ponadto z prowadzonych badań wynika, że pracownicy sektora $\mathrm{B}+\mathrm{R}$ mają tendencję do wyboru pracodawców lokalnie, co może mieć związek z tzw. czynnikami osobistymi (Stryjakiewicz 2008) lub ich aktywnością naukową (np. chęć prowadzenia nieprzerwanie pracy naukowej) (Dahl, Sorenson 2007). O silnym związku pracowników biotechnologicznych z ośrodkami naukowymi, świadczy fakt, że w firmach biotechnologicznych udział pracowników z tytułem doktora jest trzy lub dwukrotnie większy niż w innych firmach sektora B+R (Beuzekom, Arundel 2009).

Innym ważnym czynnikiem rozwoju biotechnologii jest transfer wiedzy. W aspekcie tym zwraca się przede wszystkim uwagę na gęstą sieć instytucji, która jest charakterystyczna dla obszarów zurbanizowanych (aglomeracji). Aglomeracje gospodarcze pozwalają na wykształcenie ściślejszych powiązań pomiędzy podmiotami sfery gospodarki i nauki (Domański 2000; Klasik 2009; Chojnicki, Czyż 2008; Markowski 2008). Doświadczenia amerykańskie, a następnie europejskie i azjatyckie potwierdzają pozytywny wpływ regionalnej koncentracji przemysłu i instytucji sektora biotechnologicznego (Corolleur i in. 2003; Sytch, Bubenzer 2008; Aharonson i in. 2008; Lecocq i in. 2010; Béliveau i in. 2011). Korzyści aglomeracyjne, to jest: koncentracja zróżnicowanej i rozwiniętej gospodarki oraz ośrodków badawczych, umożliwiają wymianę uzupełniającej się wiedzy (Delerue, Lejeune 2008; Goldberg $i$ in. 2008). Dodatkowym czynnikiem rozwoju sektora biotechnologii są uwarunkowania finansowe i kulturowe. Ważnym elementem są zwłaszcza postawy społeczne i władz, co jest szczególnie ważne w przypadku działań związanych z modyfikacją genetyczną lub innych „wrażliwych moralnie” działań naukowych. Innym ważnym elementem jest także dostęp- 
ność do kapitału wysokiego ryzyka, która również często uzależniona jest od postaw społecznych (Casper 2007, 2009).

Uwzględniając wszystkie powyższe czynniki można za Stevem Casper'em wyróżnić zasoby kształtujące rozwój sektora biotechnologicznego. Są to: kapitał naukowy, złożony z naukowców wraz z ich wiedzą i kreatywnością, oraz instytucje naukowe; zasoby ludzkie związane z nauką, przedsiębiorczością i zarządzaniem oraz instytucje rynku pracy. Ostatnim czynnikiem jest kapitał finansowy czyli inwestorzy i instytucje finansowe zaangażowane w przedsięwzięcia wysokiego ryzyka. Dodatkowo zasoby te powinna uzupełniać bogata sieć społecznych powiązań łącząca: naukowców, przedsiębiorców, menedżerów i inwestorów. Pozwalają one na szybki przepływ informacji zarówno wewnątrz firm i instytucji, jak i pomiędzy nimi (Casper, Murray 2005; Casper 2009).

W oparciu o powyższe przesłanki celem artykułu jest przedstawienie regionalnego zróżnicowania, na poziomie NUTS $2^{2}$, rozwoju sektora biotechnologicznego w krajach Unii Europejskiej ${ }^{3}$. Analiza regionalnego zróżnicowania zostanie dokonana w oparciu o regionalne rozmieszczenie ilości i natężenia zgłoszeń patentów biotechnologicznych (European Patent Office, EPO). Zgłoszenia patentowe stanowią z jednej strony zasoby umożliwiające rozwój przemysłu biotechnologicznego, a z drugiej określają regiony rozwoju innowacji biotechnologicznych. Następnym elementem analizy jest porównanie regionalnego rozmieszczenia firm biotechnologicznych. Zostanie zatem poddane badaniu rozmieszczenie najważniejszych czynników warunkujących komercjalizację biotechnologii. W oparciu o rozmieszczenie patentów biotechnologicznych i firm zostanie podjęta próba delimitacji głównych regionów związanych z sektorem biotechnologicznym w Europie. Na koniec analizie poddane zostaną czynniki wpływające lub towarzyszące regionalnemu rozmieszczeniu sektora biotechnologicznego. W badaniach wykorzystano dane statystyczne publikowane przez Eurostat oraz pochodzące $\mathrm{z}$ bazy teleadresowej szwajcarskiej firmy Biotechgate.

\section{REGIONALNE ZRÓŻNICOWANIE ZGŁOSZEŃ PATENTÓW BIOTECHNOLOGICZNYCH}

Podstawowym czynnikiem warunkującym możliwość wykorzystania jakiegokolwiek rozwiązania naukowego w produkcji jest jednoznaczne określenie praw własności do tego wynalazku. Najbardziej powszechnym, choć niedoskonałym i często krytykowanym, jest patent. Komercjalizacja biotechnologii wymaga zazwyczaj długich terminów realizacji, co głównie wynika ze względu na trudności pozyskania kapitału na inwestycje o wysokim ryzyku. Stąd tak ważne są w biotechnologii regulacje prawne oraz ochrona praw własności intelektualnej. O znaczeniu ochrony patentowej może świadczyć fakt, że według ekspertów europejska legislacja patentowa jest w dużej mierze odpowiedzialna za istniejące różnice w postępie biotechnologii w Ameryce Północnej i Unii Europejskiej (Overwalle 2010). Również działania wielu europejskich instytucji naukowych (m.in. uniwersytetów) dotychczas nie uwzględniają w swych działaniach uwarunkowań komercyjnych, zmuszając naukowców do

${ }^{2}$ Od Nomenclature des Unites Territoriales Statistique, jednostki terytorialnej w UE dla celów statystyki terytorialnej; poziom 2, czyli poziom województw (tzw. regiony).

${ }^{3} \mathrm{~W}$ badaniach analizie poddano regiony krajów należących do UE z $2011 \mathrm{r}$. (przyp. autora). 
publikacji wyników badań przed dokończeniem procesów związanych z ich ochroną prawną i jej finansowaniem. Rozmieszczenie zgłoszeń patentów biotechnologicznych świadczy zatem nie tylko o lokalizacji działalności naukowej w tym sektorze, ale stanowi również podstawę do rozwoju firm biotechnologicznych w danym regionie.

W badanych latach 1977-2008 w krajach Unii Europejskiej nastąpił wyraźny wzrost liczby zgłoszeń patentów, od 50 w 1977 r. do ponad 3000 w 2001 r. (ryc. 1). Wzrostowi ilości patentów towarzyszył zarówno wzrost liczby regionów w których nastąpiło zgłoszenie patentu, od 33 do 228 w 2007 roku, jak i wzrost średniej ilości patentów w regionach z 1,6 do 14,8 na początku XXI w. Również w badanym okresie w regionach wzrósł udział patentów biotechnologicznych na tle wszystkich patentów z 2,5 do 6,3\% w 2001 roku.

Dynamika zgłoszeń patentów biotechnologicznych w regionach Europy wykazuje wyraźną periodyczność. Od lat siedemdziesiątych do początku lat 90-tych XX wieku nastąpił umiarkowany wzrost wszystkich analizowanych wartości. Następnie obserwujemy wyraźne przyśpieszenie wzrostu liczby zgłoszeń patentowych, które trwa do końca stulecia. XXI wiek przynosi powolny spadek liczby patentów wraz z dalszym wzrostem liczby regionów. W 2008 roku następuje drastyczny spadek wszystkich analizowanych wartości. Jest to wynikiem światowego załamania koniunktury w latach 2008/2009, które spowodowało w Europie spadek liczby działających podmiotów z branży biotechnologii o $2 \%$ oraz globalny spadek dochodów firm biotechnologicznych o ok. 9\% (Beyond Borders Global Biotechnology Report 2010). Spowodowało to spadek inwestycji w badania i rozwój średnio o $21 \%$, co z kolei wpłynęło na obserwowany spadek liczby patentów.

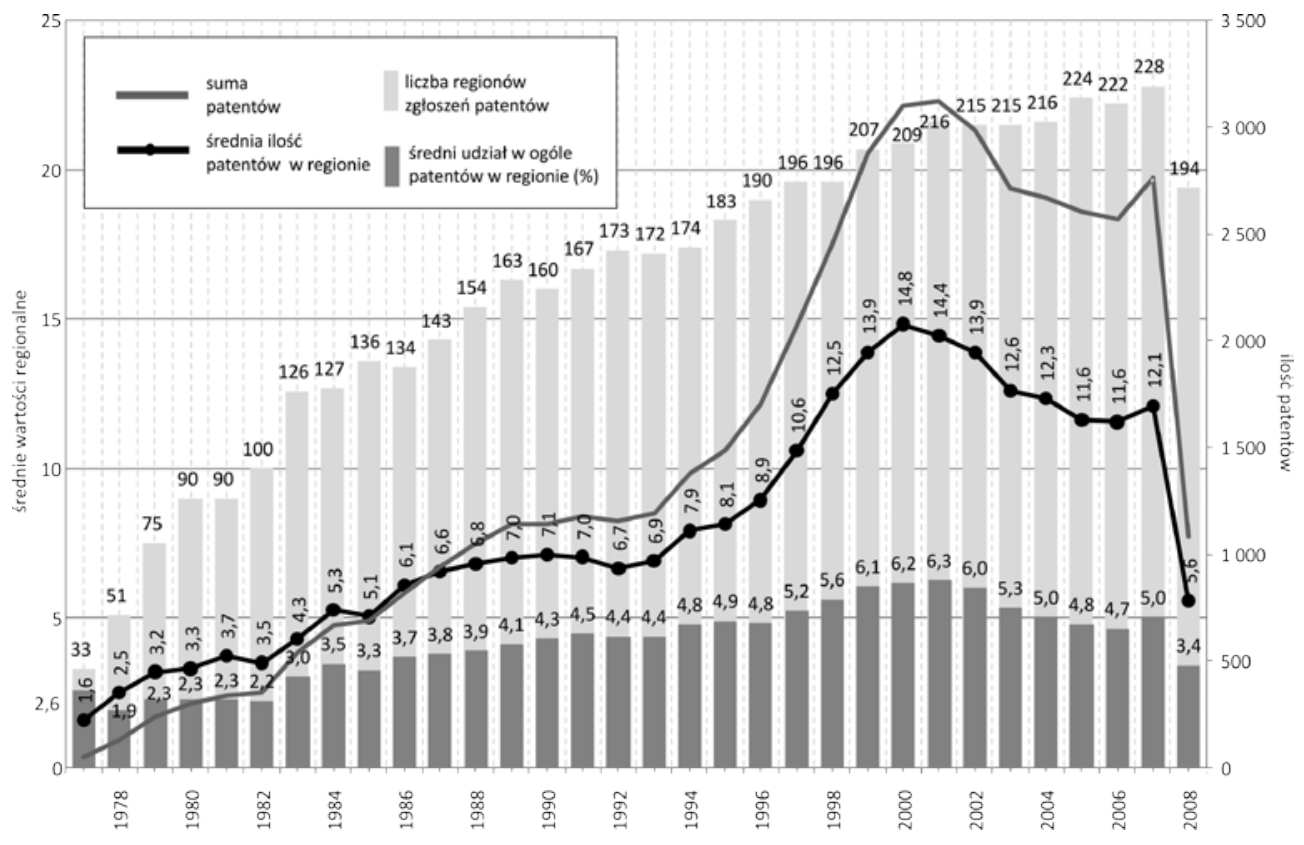

Ryc. 1. Liczba zgłoszonych patentów biotechnologicznych w UE w latach 1977-2008

Źródło: obliczenia własne na podstawie danych Eurostat 
Spośród państw Unii Europejskiej na pierwszym miejscu według liczby zgłoszeń patentów biotechnologicznych znajdują się wysoko rozwinięte gospodarczo kraje, tj. Niemcy, Wielka Brytania, Francja. Następne w kolejności są kraje Beneluksu oraz Włochy i Austria (ryc. 2A). Liczba patentów zgłoszonych w pozostałych krajach jest wyraźnie mniejsza. Jednakże od początku XX w. można zauważyć proces stopniowego wyrównywania poziomu zgłoszeń patentowych w poszczególnych krajach. Proces ten potwierdza analiza regionalnego zróżnicowania ilości zgłoszeń patentowych na podstawie krzywej dopasowania rozkładu normalnego (ryc. 2B). Analizując kształt krzywych można stwierdzić, że w badanym okresie nastąpił spadek koncentracji, któremu towarzyszył wzrost średniej ilości patentów w regionach.

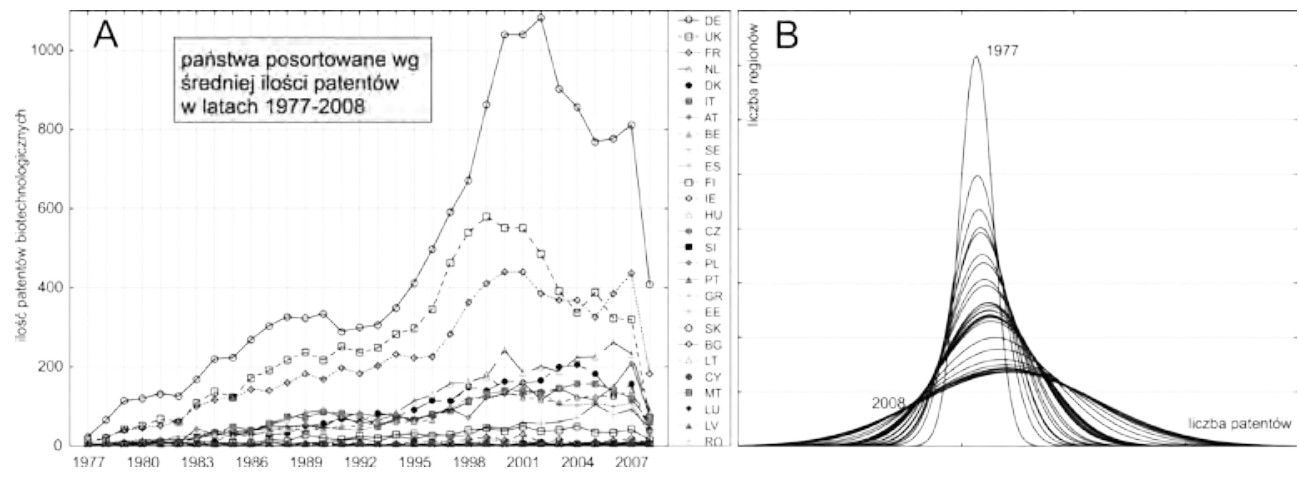

Ryc. 2. Liczba zgłoszonych patentów biotechnologicznych w regionach (A) oraz ich zróżnicowanie (B) w UE w latach 1977-2008

Źródło: obliczenia własne na podstawie danych Eurostat

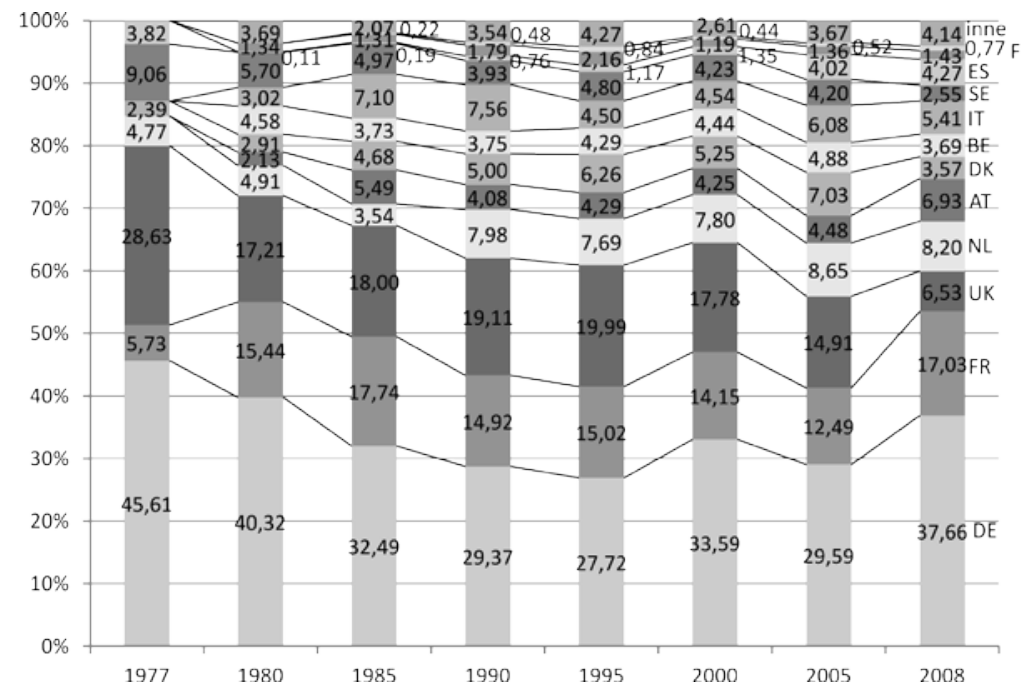

Ryc. 3. Udział krajów w ogóle zgłoszeń patentów biotechnologicznych w UE w latach 1977-2008

Źródło: obliczenia własne na podstawie danych Eurostat 
Dominację Niemiec w rozwoju zasobów biotechnologii potwierdza udział tego kraju w ogóle zgłoszonych patentów biotechnologicznych w Unii (ryc. 3). Niemieckie zgłoszenia stanowią ok 30\% ogółu europejskich patentów biotechnologicznych. Następnymi krajami według udziału zgłoszeń jest Francja (ok. 15\%) oraz Wielka Brytania i Holandia. W zmianach udziału poszczególnych krajów charakterystyczny jest spadek liczby zgłoszeń patentów biotechnologicznych w Wielkiej Brytanii, przy wzroście udziału krajów z poza tzw. Wielkiej Trójki np. Holandii lub Hiszpanii.

Powyższe zmiany w strukturze udziału poszczególnych krajów w zgłoszeniach patentów biotechnologicznych wynikają z faktu, że od końca lat 70-tych XX w. najwyższy średnioroczny wzrost ilości patentów ${ }^{4}$ wykazują regiony w krajach peryferyjnych Europy (ryc. 4). Były to początkowo kraje południowe (Włochy, Hiszpania, Portugalia) i Finlandia. Najwyższy wzrost patentów nastąpił na przełomie XX w. i XXI w. głównie w regionach Europy Środkowo-Wschodniej (Węgry, Estonia, Polska, Bułgaria, Czechy, Litwa) oraz w Skandynawii i na południu Europy. Również to regiony w krajach peryferyjnych najmniej odczuły skutki spadku koniunktury w 2008 roku. O szybszym wzroście liczby patentów biotechnologicznych w regionach peryferyjnych może świadczyć zestawienie tempa wzrostu w latach 1990-2000 oraz 2000-2007 (ryc. 4).

Kraje w których regiony charakteryzował wysoki wzrost zgłoszeń patentów pod koniec $\mathrm{XX}$ wieku, posiadały odpowiednio najniższe tempo wzrostu zgłoszeń na początku XXI w. Według tempa zmiany liczby zgłoszeń patentów biotechnologicznych w jednej grupie znalazły się rozwinięte kraje Europy Zachodniej (Niemcy, UK, Francja, Dania, Belgia, Holandia, Włochy, Austria, Szwecja), natomiast w drugiej kraje Europy Wschodniej (Bułgaria, Polska, Czechy, Litwa, Słowenia) oraz Finlandia i Luksemburg.

Analizując regionalne zróżnicowanie rozmieszczenia zgłoszeń patentowych z biotechnologii w latach 1977-2008 można zauważyć, że zgłoszenia patentowe z biotechnologii początkowo skoncentrowane były głównie w regionach stołecznych lub metropolitalnych krajów Europy Zachodniej (ryc. 5). W następnych latach zgłoszenia odnotowano w coraz dalszych regionach na północ, południe i wschód od tzw. Europejskiego Banana. Jednakże, pomimo rozprzestrzeniania się zgłoszeń patentowych na obszarze całego kontynentu, co świadczy o rozwoju nauk biotechnologicznych i ich komercjalizacji, obszary rdzeniowe Europy Zachodniej dalej wyraźnie dominują nad nowymi regionami Unii.

Supremację wielkich metropolii w rozwoju innowacyjności biotechnologicznej potwierdza obraz średniej liczby zgłoszeń patentów biotechnologicznych w regionach Unii Europejskiej w latach 1977-2008. Dominują zatem regiony związane z dużymi aglomeracjami stanowiącymi zarazem centra gospodarcze, jak i naukowo-badawcze. Są to: region Île-de-France z metropolią paryską, Górna Bawaria z Monachium (Max Planck Institute for Biochemistry), duński region stołeczny z Kopenhagą, Darmstadt z Frankfurtem nad Menem (Max Planck Institute for Biophysics), region Rodan-Alpy z Lyonem oraz czternastoma sieciami badań, piętnastoma klastrami konkurencyjności (bieguny konkurencyjności) i dziesięcioma lokalnymi biegunami rozwoju, Berlin, Wschodnia Anglia z Cambridge i Luton, region Berkshire z Buckinghamshire i Oxfordshire z Oxford, Karlsruhe z uczelniami technicznymi z węzłem wiedzy i innowacji oraz Holandia Południowa z Rotterdamem. Dodatkowo należy

${ }^{4} \mathrm{~W}$ obliczeniu średniorocznej zmiany ilości zgłoszeń patentowych pominięto jednostkowe wartości, a odniesiono się do minimalnie dwuletniego okresu, w którym w regionach odnotowano zgłoszenia patentowe (przyp. autora). 
zaznaczyć, że we wszystkich tych regionach usytuowane są klastry biotechnologiczne, co potwierdza znaczenie transferu wiedzy i współpracy, nie tylko w aspekcie aglomeracji lecz również działań instytucjonalnych.
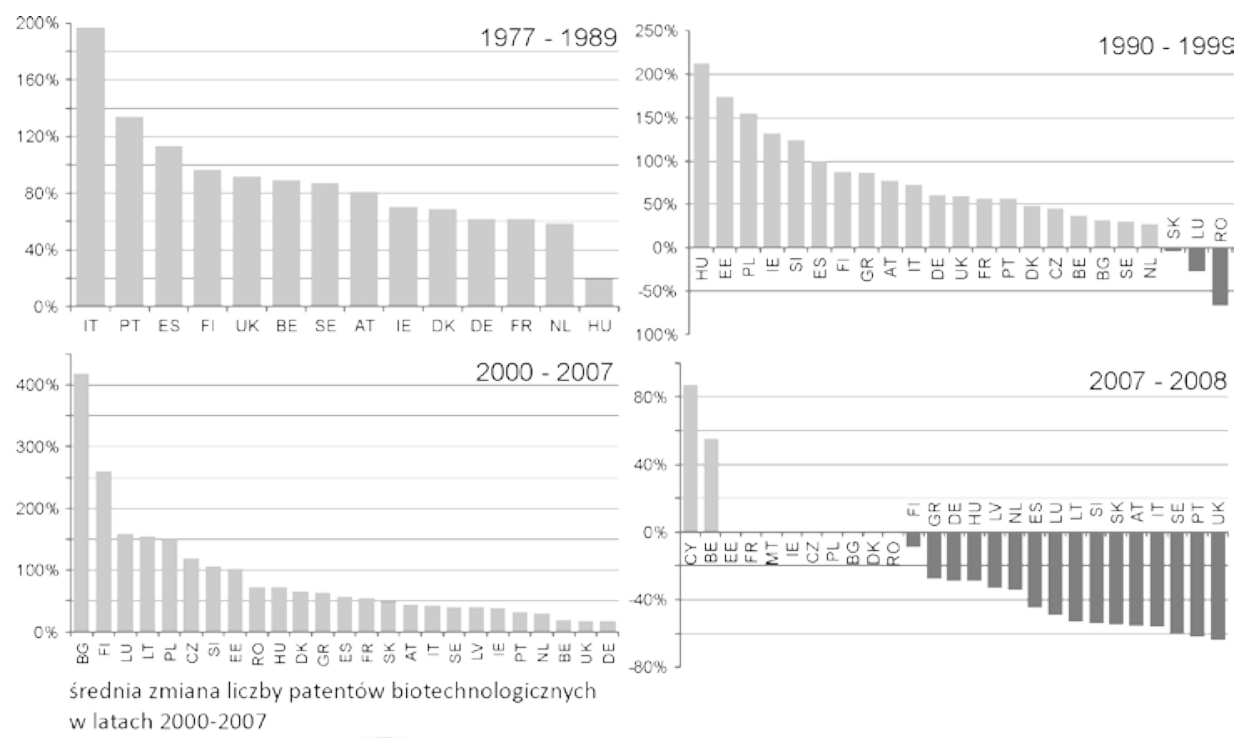

w latach 2000-2007

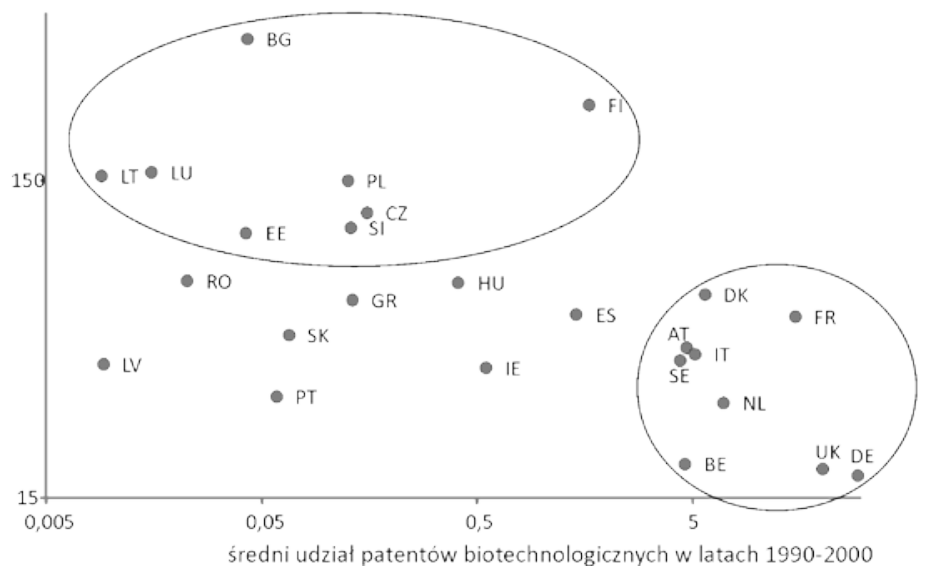

Ryc. 4. Średnioroczna zmiana ilości zgłoszeń patentów biotechnologicznych w regionach krajów UE w latach 1997-2008 (rok poprzedni=100\%)

Źródło: obliczenia własne na podstawie danych Eurostat 

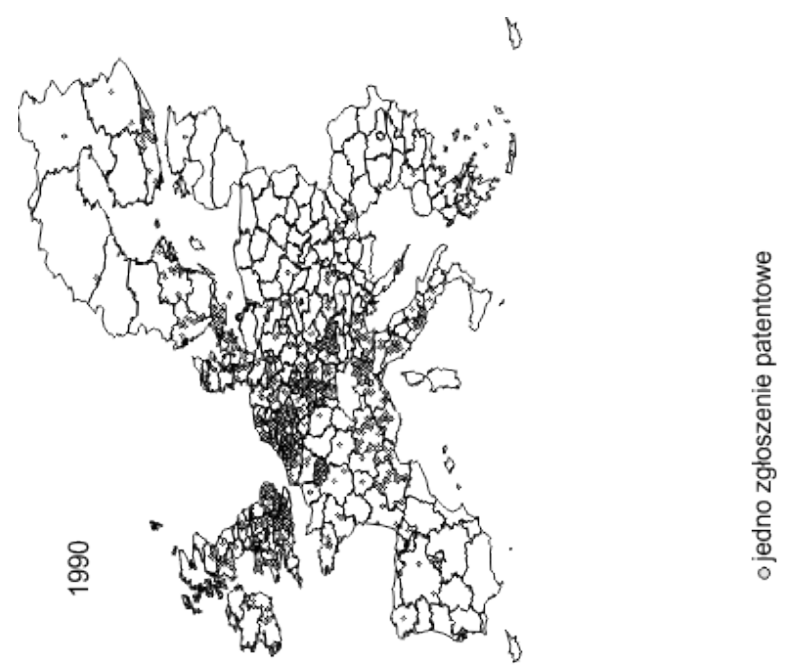

-
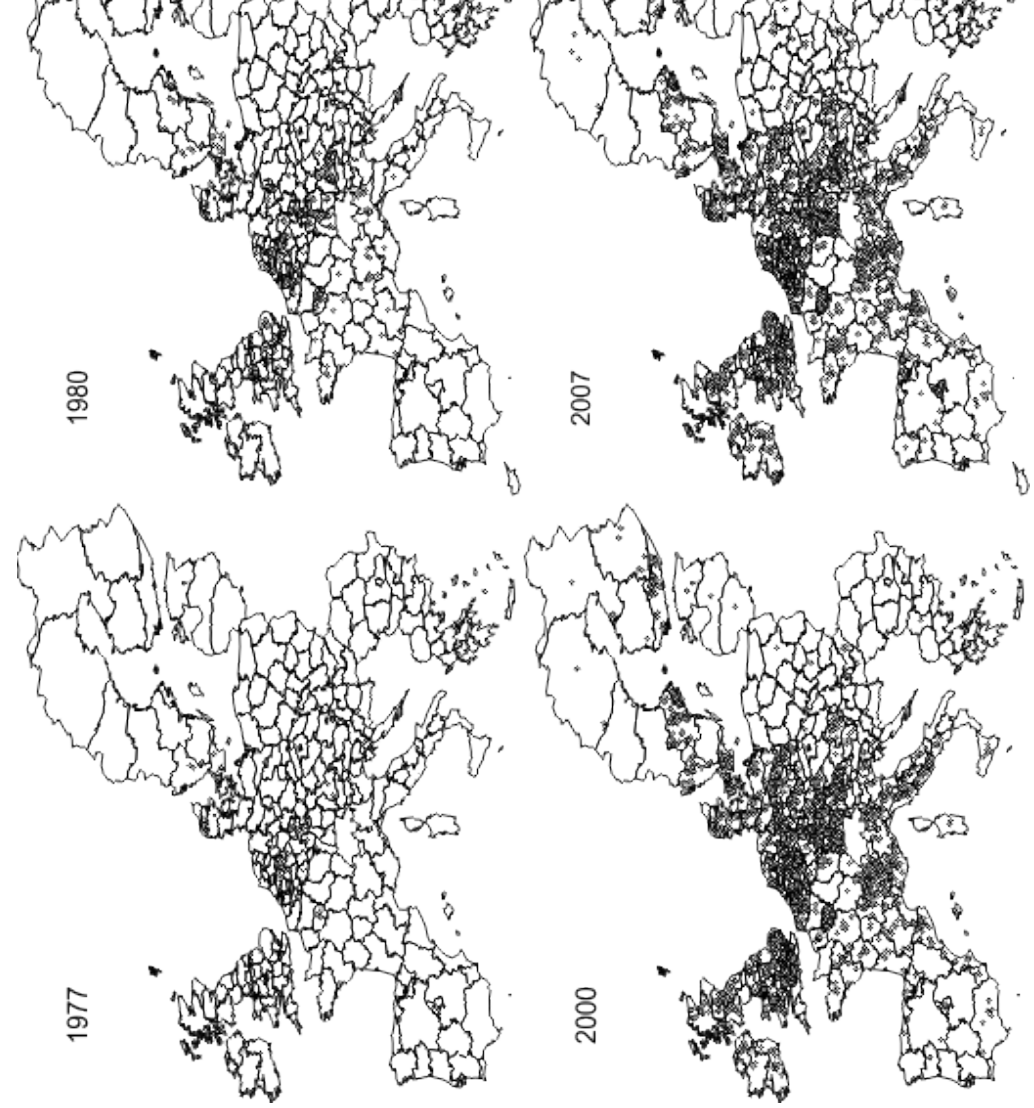


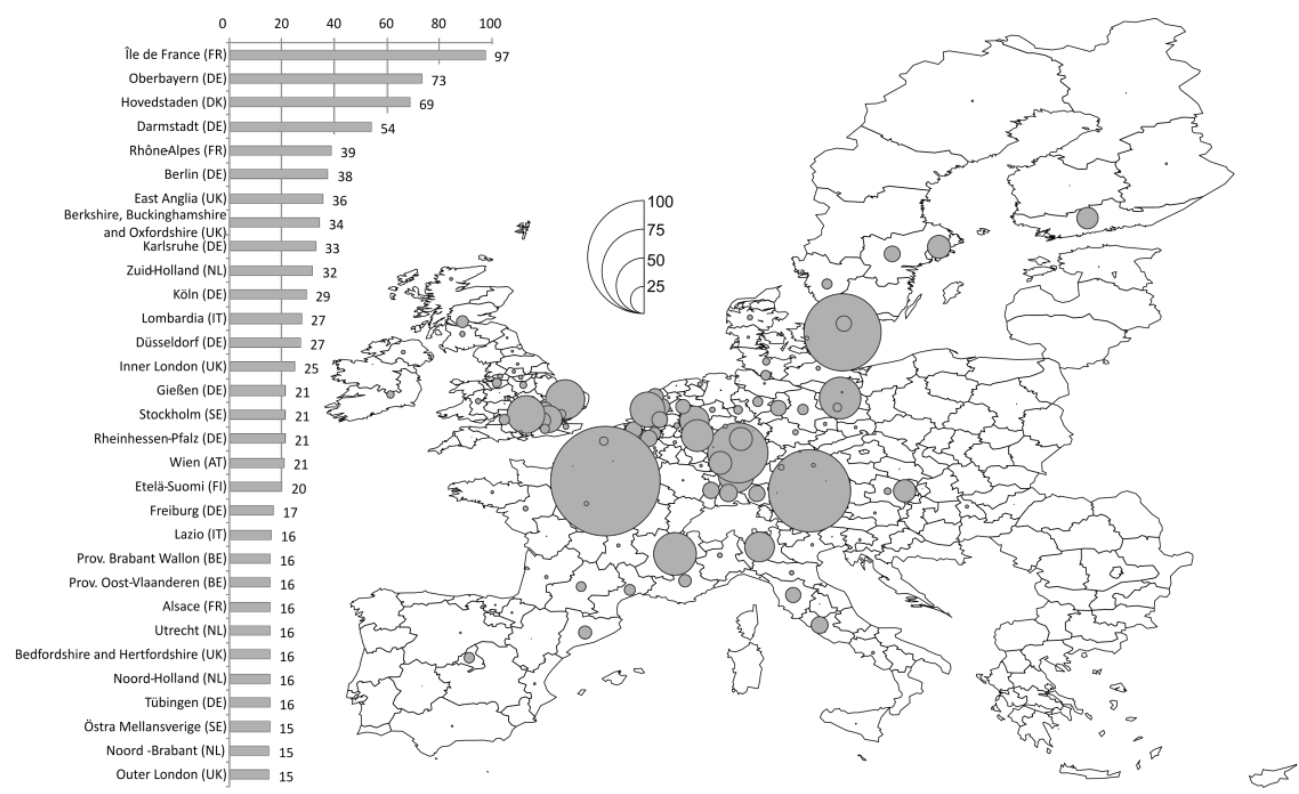

Ryc. 6. Średnia liczba zgłoszonych patentów biotechnologicznych w regionach UE w latach 1977-2008

Źródło: obliczenia własne na podstawie danych Eurostat

Według średniego udziału biotechnologicznych zgłoszeń patentowych na tle wszystkich zgłoszonych patentów w regionie można zauważyć, że w regionach rozwiniętych udział ten jest mniejszy niż w regionach peryferyjnych (ryc. 7). W przypadku rozwiniętych regionów biotechnologia jest jedną z wielu innych gałęzi innowacji, co związane jest ze strukturą instytucji badawczych i naukowych wykształconych we wcześniejszym okresie. Natomiast duży udział patentów biotechnologicznych wśród wszystkich patentów w regionach Europy Wschodniej i Południowej lub Szkocji, to z jednej strony scheda po okresie opóźnień rozwojowych, małej komercjalizacji nauki oraz specyfiki regionów, które często związane były z działalnością pozaprzemysłową np. rolnictwem. Zjawisko to potwierdza zmiana udziału patentów biotechnologicznych w badanych latach.

Analizując przestrzenny rozkład regionów o najwyższym udziale zgłoszeń biotechnologicznych można zaobserwować, że od lat siedemdziesiątych XX w. następuje przesuwanie ich lokalizacji od centrum gospodarczego Europy ku regionom zewnętrznym. Początkowo w latach dziewięćdziesiątych XX w. są to regiony Półwyspu Iberyjskiego, wschodnie regiony Niemiec, zachodnie regiony Polski oraz regiony Czech, Słowacji i Węgier. W XXI w. były to natomiast regiony Szkocji, Polski północno-wschodniej, Grecji i Portugalii oraz państw nadbałtyckich. Można zatem zaryzykować stwierdzenie, że biotechnologia jest domeną nie tylko rozwiniętych gospodarczo regionów ale również prężnie rozwija się w regionach rozwijających się lub związanych z tradycyjnymi sektorami gospodarki. Przykładem może być region Wschodniej Finlandii (Itä-Suomi), którego gospodarka zdominowana przez przemysł drzewny porównywana była do województwa Warmińsko-Mazurskiego, a obecnie jest uznany za najbardziej innowacyjny region biotechnologiczny Finlandii (Innovation in the Baltic Sea Region 2011). 


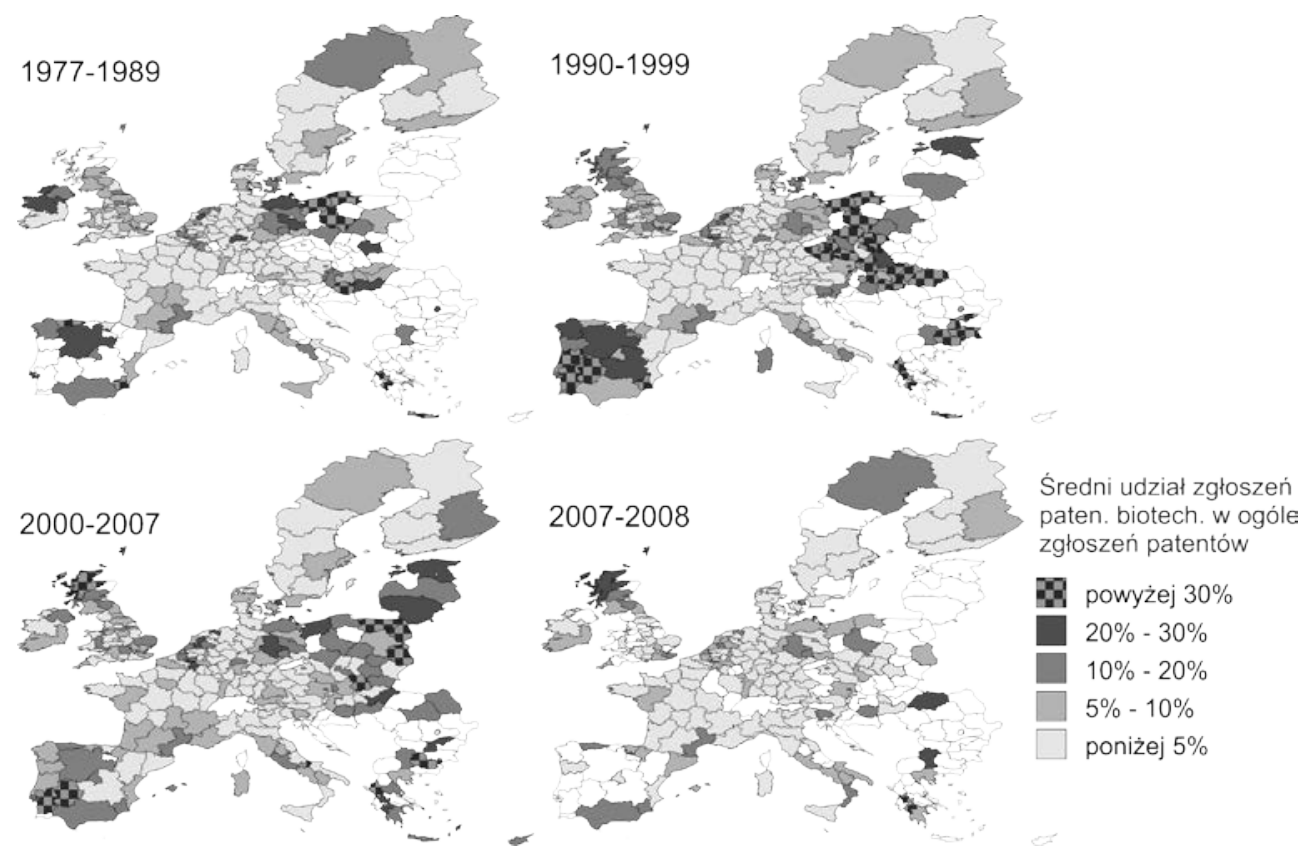

Ryc. 7. Średni udział zgłoszeń patentów biotechnologicznych w ogóle wszystkich zgłoszeń w UE w latach 1977-2008

Źródło: obliczenia własne na podstawie danych Eurostat

Najwyższy średni udział patentów biotechnologicznych w ogólnej liczbie wszystkich patentów w regionie w badanym okresie odnotowały regiony Europy wschodniej i południowej (ryc. 8). W trzech regionach w latach 1977-2008 zgłoszono jedynie patenty biotechnologiczne. Były to wschodnie regiony Polski: Warmińsko-Mazurski (patenty związane z przemysłem mleczarskim zgłoszone przez Uniwersytet Warmińsko-Mazurski) i Podlaski (patenty medyczne związane z działalnością Wschodniego Klastera Medycznego Białostockiego Parku Naukowo-Technologicznego oraz Klastera Zielonych Technologii) oraz region butgarski Yugoiztochen z Burgas Free University (biotechnologia) w mieście Burgas oraz Centralnym Laboratorium Badawczym. Ogólnie można przyjąć, że w większości regiony o wysokim odsetku patentów biotechnologicznych posiadały najniższy wskaźnik gospodarki opartej na wiedzy (Cooke, De Laurentis 2002; Cooke 2003) (Knowledge Economy Index) (Wasiak 2007) oraz małą ilość zgłoszeń patentów biotechnologicznych. 


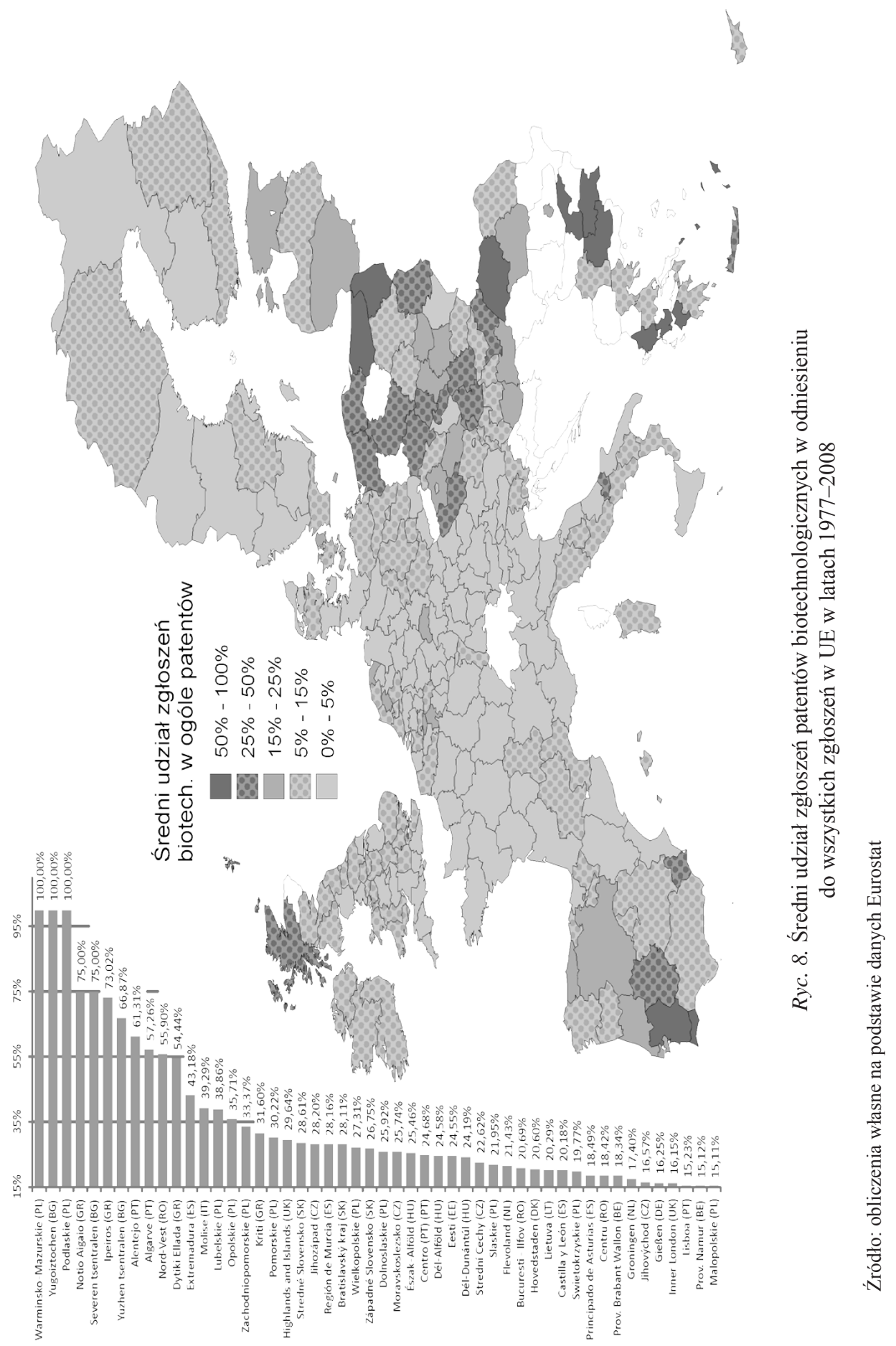


Rozpatrując średnie tempo wzrostu zgłoszeń biotechnologicznych w okresie od końca lat siedemdziesiątych XX w. można zauważyć, że najwyższe wartości wzrostu odnotowano na obszarze Europy Zachodniej. Obszar o wysokim wzroście wartości zgłoszeń biotechnologicznych obejmuje obszar od Kornwalii i południowej Anglii na północy kontynentu, po Półwysep Apeniński na południu oraz środkową Polskę i Finlandię na wschodzie Europy. Spośród wszystkich regionów Unii Europejskiej największy średni wzrost zgłoszeń patentowych $\mathrm{z}$ biotechnologii w stosunku do lat poprzednich miały regiony: Devon, z Uniwersytetem w Exeter i założonym w 2000 roku Centrum Innowacji Biomedycyny, region Itä-Suomi z rozwiniętym wydziałem zdrowia na Uniwersytecie Wschodniej Finlandii, region łódzki z Politechniką Łódzką (bionanoceluloza, implanty medyczne), Saarbrücken z wydziałem inżynierii biomedycznej w Hamburgu i Centrum bioinformatyki, Centralne Morawy z Uniwersytetem Palackiego i Zlinie, region Tyrolu z 4000 naukowców pracującymi w sektorze Life Science (Innsbruck) oraz wielką firmą Sandoz w Kundl, region Jihovýchod z Central European Institute of Technology, Czech Central Institute of Technology Brno oraz region Sycylia z Etna Valley: Sicilian Universities (Catania, Messina, Palermo), Science and Technology Park of Sicily, Etna Biotech. Największy wzrost zgłoszeń patentów nastąpił zatem w regionach o dużym kapitale ludzkim, związanym $\mathrm{z}$ instytucjami $\mathrm{B}+\mathrm{R}$ oraz dużym potencjale gospodarczym umożliwiającym bezpośredni transfer innowacji do przedsiębiorstw produkcyjnych i usługowych. Zależność tę potwierdza analiza regionalnego zróżnicowania potencjału ludzkiego w Europie podjęta m.in. przez Borowiec, Dorockiego, Jenner (2009), oraz analiza regionalnego zróżnicowania potencjału gospodarczego podejmowana m.in. przez Kilar, Rachwała, Wiedermanna (2009).

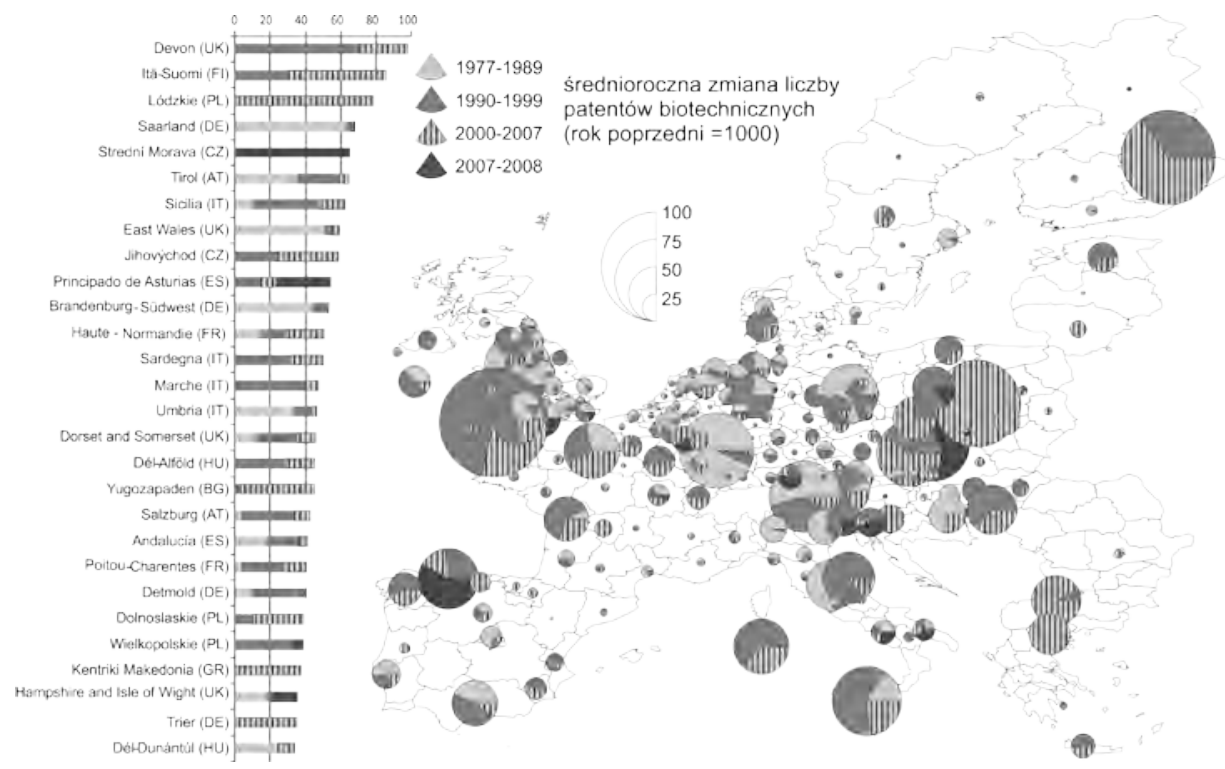

Ryc. 9. Średnioroczne tempo wzrostu zgłoszeń liczby patentów biotechnologicznych w regionach UE w latach 1977-2007

Źródło: obliczenia własne na podstawie danych Eurostat 

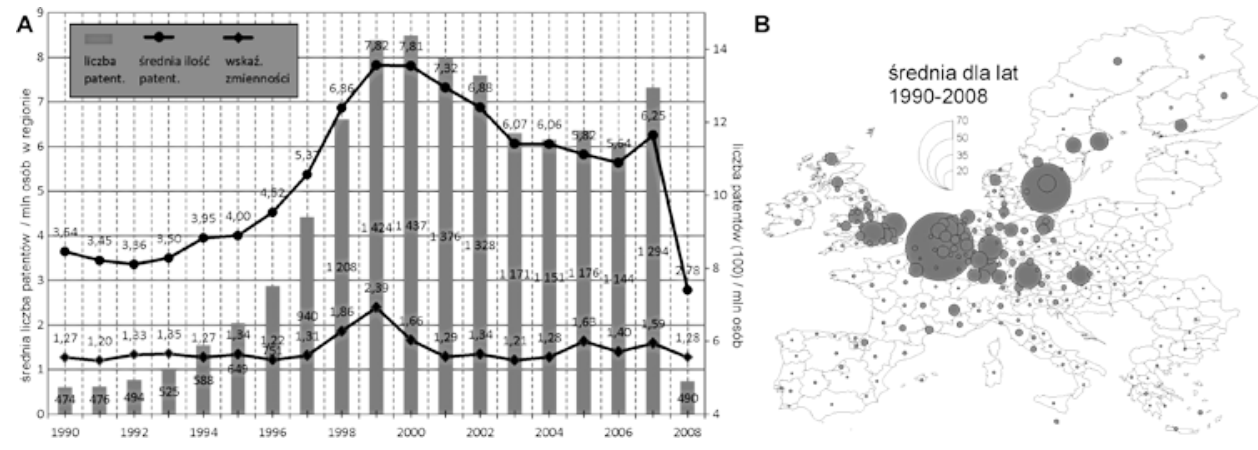

Ryc. 10. Liczba zgłoszeń patentów biotechnologicznych na mln osób (A) i średnia liczba patentów w regionach UE (B) w latach 1990-2008

Źródło: obliczenia własne na podstawie danych Eurostat

W badanym okresie nastąpiło także regionalne zróżnicowanie tempa wzrostu zgłoszeń patentów biotechnologicznych. W pierwszym badanym okresie do lat dziewięćdziesiątych XX w. największy wzrost odnotowały regiony najsilniej rozwinięte, związane z rdzeniowym obszarem gospodarczym Europy, m.in. Brandenburgia, Wschodnia Walia, Umbria, Tyrol. W następnych latach najsilniejszy rozwój nauk biotechnologicznych nastąpił w Kornwalii (Devon), Wschodniej Finlandii, Sycylii oraz na wschodzie i południu Europy.

Innym wskaźnikiem rozwoju biotechnologii jest wielkość współczynnika natężenia liczby patentów na milion osób. Również w tym przypadku w dynamice rozkładu liczby patentów obserwujemy wzrost ich zgłoszeń, który trwał do 2000 roku, a po którym to następuje jego wyraźny spadek (ryc. 10A). W regionalnym rozmieszczeniu patentów biotechnologicznych w przeliczeniu na liczbę ludności wyraźnie zaznacza się aktywność innowacyjna w regionach najbardziej rozwiniętych krajów Europy: Beneluksu, Niemiec, Wielkiej Brytanii, Skandynawii, Austrii, Irlandii oraz południowej Francji (powyżej 6 patentów na mln os.) (ryc. 10B). Natomiast regiony Europy Wschodniej i Południowej wyraźnie odcinają się od zachodu Europy niskim wskaźnikiem patentów, nie przekraczającym dwóch patentów na milion osób.

Spośród regionów z wysokim udziałem potentatów biotechnologicznych w przeliczeniu na milion mieszkańców wyróżniają się dwa regiony: Prowincja Brabancja Walońska (Brabant Wallon) i region Stołeczny (Hovedstaden) (ryc. 11). W przypadku belgijskiego regionu średnia ilość zgłoszeń patentów biotechnologicznych dla lat 1990-2008 wynosi prawie siedemdziesiąt na milion osób. Tak wysoki wskaźnik jest wynikiem lokalizacji w prowincji w 1971 roku największego w Walonii (231 ha) i pierwszego tego typu w Belgii parku naukowego Louvain-la-Neuve Science Park. Ponadto na terenie regionu ma siedzibę jedna z największych na świecie firm farmaceutycznych GlaxoSmithKline Biologicals ${ }^{5}$. Ponadto region charakteryzuje się wysokimi wskaźnikami rozwoju wysokiej technologii co plasuje go w czołówce innowacyjnych regionów Europy (Science, technology and innovation in

${ }^{5}$ Główne centrum badawczo-naukowe GSK zostało zlokalizowane w Anglii w Stevenage Bioscience Catalyst w biskiej odległości od ośrodków uniwersyteckich Cambridge, Oxfordu i Londynu w tzw. Golden Triangle (przyp. autora). 
Europe 2011). Następny w kolejności, ze średnią ok. 50 patentów na milion mieszkańców, jest duński region Hovedstaden. Również w tym przypadku o tak dużej aktywności patentowej decyduje wysoki poziom rozwoju regionu oraz zaplecze intelektualne. Głównymi ośrodkami innowacji biotechnologicznej są największy w północnej Europie Uniwersytet w Kopenhadze, Uniwersytet Techniczny i Wyższa Szkoła Biznesu. Również na terenie regionu od 1986 roku działa inkubator i park naukowy - Symbion, grupujący ok 200 firm z sektora: IT, biotechnologii i medycyny. W pozostałych regionach średnia ilość patentów na milion mieszkańców nie przekraczała 25 zgłoszeń. Regiony z wartościami powyżej 10 patentów skupione są w najbardziej rozwiniętych gospodarczo regionach Europy (południe Wielkiej Brytanii, kraje Beneluksu, Niemcy, Austria, południowa Szwecja).

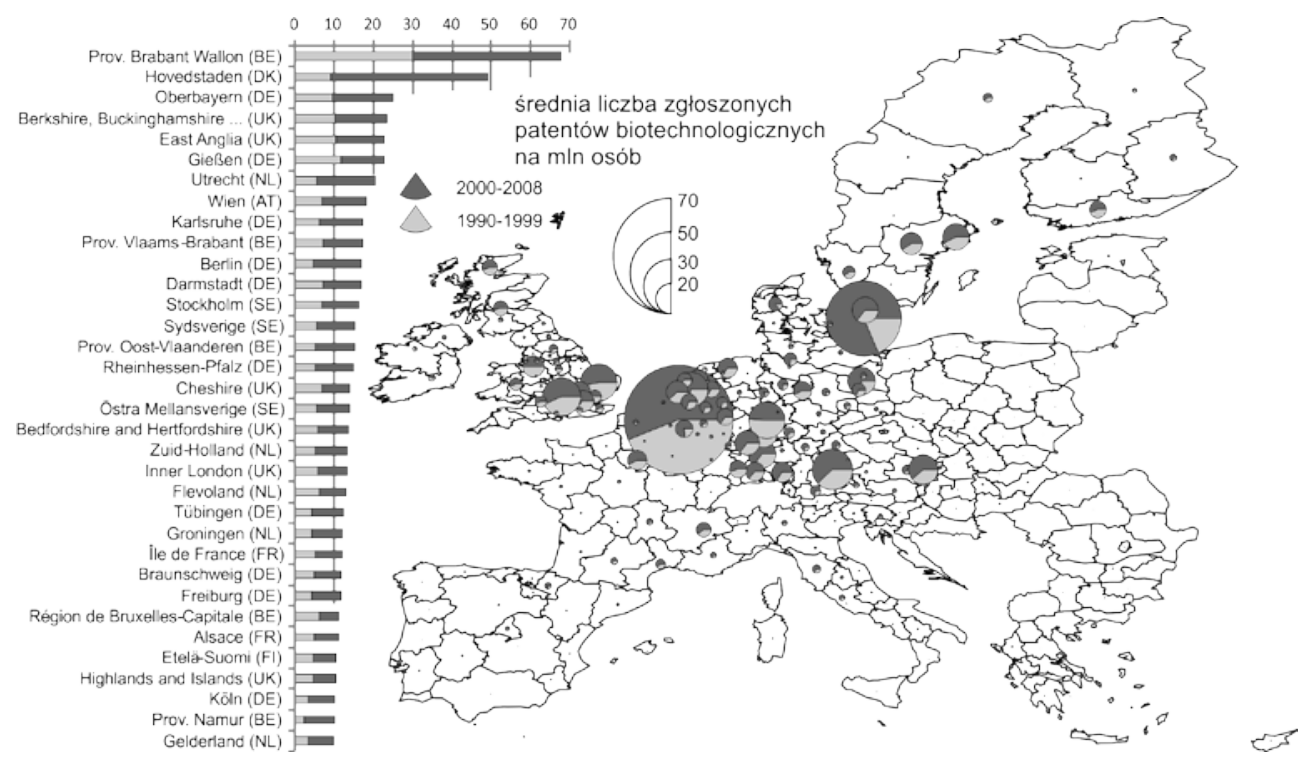

Ryc. 11. Średnia liczba zgłoszonych patentów biotechnologicznych na mln osób w regionach UE w latach 1990-2008

Źródło: obliczenia własne na podstawie danych Eurostat

Wyróżniony obszar o wysokiej liczbie zgłoszeń patentów biotechnologicznych przestrzennie jest zbliżony do modelu Trójkąta Europejskiego (Central Triangle, Central European triangle, Major Triangle) (Szabó 2007) z wierzchołkami Oxford - München (lub Wiedeń) - Kopenhaga (lub Sztokholm). Biotechnologia jako nauka nie jest zatem związana jedynie z poziomem rozwoju gospodarczego (model Blue Banana) lub poziomem rozwoju wysokiej technologii (European sunbelt, Golden Banana), ale wydaje się, że jej rozwój związany jest również z czynnikami kulturowymi (zróżnicowanie północ-południe) oraz aktywnością władz lokalnych i państwowych w sferze B+R oraz transferu wiedzy.

Analizując dynamikę wzrostu liczby zgłoszeń patentów biotechnologicznych na milion mieszkańców w latach 1990-2008 najwyższy wzrost w stosunku do lat poprzednich odnotowały regiony peryferyjne Europy o małej ilości patentów we wcześniejszym okresie. 
W trzech regionach: Łódzkie (79\%), Centralne Morawy (63\%) i Devon (58\%) średni wzrost przekroczył $50 \% \mathrm{~W}$ stosunku do roku poprzedniego (ryc. 12A). W przypadku polskiego i czeskiego regionu, jak i innych wschodnich regionów Europy wzrost nastąpił głównie po 2000 roku. Natomiast w przypadku regionu Devon, podobnie jak w większości regionów środkowo-zachodniej i południowej Europy (Niemcy, Zachodnia Polska, Czechy, Austria, Włochy) większy udział wzrostu zgłoszeń patentowych miał miejsce w XX w. Tak więc największy wzrost liczby zgłoszeń patentów biotechnologicznych dotyczył głównie regionów o najmniejszym udziale patentów zarówno w okresie lat 90. XX w., jak i początkach XXI w. (ryc. 12B)

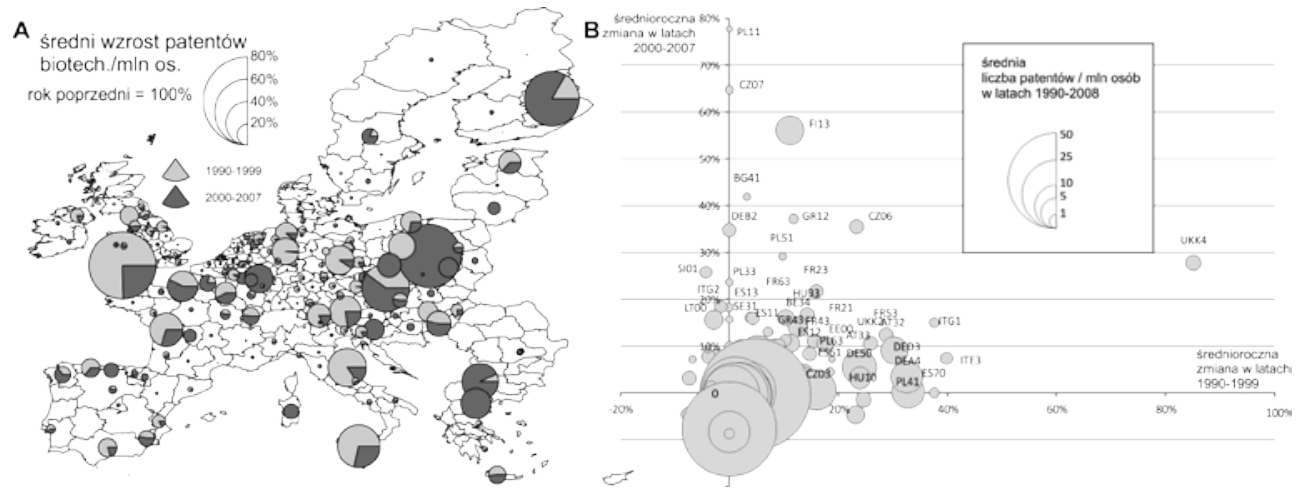

Ryc. 12. Średni wzrost patentów biotechnologicznych/mln os. w regionach UE w latach 1990-2008 (A) oraz zestawienie regionalnego tempa zmian w latach 1990-99 i 2000-07 (B).

Źródło: obliczenia własne na podstawie danych Eurostat

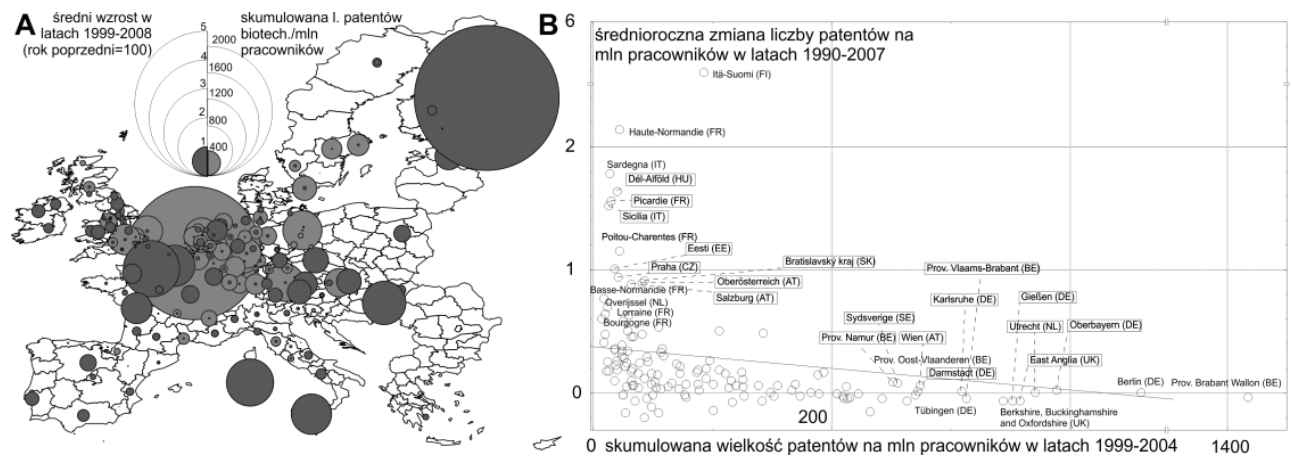

Ryc. 13. Skumulowana liczba zgłoszeń patentów biotechnologicznych na mln pracujących oraz regionalne zróżnicowanie tempa zmian średniej ilości patentów w latach 1990-2008 (A) oraz zestawienie skumulowanej liczby patentów w latach 1999-2004 i regionalnego tempa zmiany w latach 1990-99 i 2000-07 (B)

Źródło: obliczenia własne na podstawie danych Eurostat 
Natomiast w przypadku natężenia zgłoszeń patentowych w przeliczeniu na milion pracujących od końca XX w. wyróżnia się region Brabancja Walońska (ok. 2000 zgłoszeń), natomiast w przypadku tempa zmian, które wynosiły jedynie kilka procent, region wschodniej Finlandii.

Regiony z największą liczbą zgłoszeń patentów biotechnologicznych zlokalizowane były we wspomnianym wyżej centralnym trójkącie europejskim. Wzrost patentów nastąpił natomiast w regionach o niskiej liczbie patentów, jednakże głównie w Europie Zachodniej: Francji (Górna Normandia, Pikardia, Poitou-Charentes), we Włoszech (Sardynia, Sycylia), ale także na Węgrzech (Dél-Alföld-Uniwersytecie w Szeged) oraz w regionach metropolii Bratysławy i Pragi. Można zatem przypuszczać, że rozwinięte regiony Europy Zachodniej charakteryzują się wyższym wskaźnikiem produktywności (kreatywności) pracowników sektora biotechnologii. Wydaje się to być spowodowane przewagą technologiczną (infrastrukturą badawczą oraz poziomem rozwoju gospodarki) oraz zasobami kapitału ludzkiego (przyciąganie ludzi z dużym potencjałem w sektorze naukowym i biznesu), które swoje źródło mają w uwarunkowaniach historycznych.

\section{REGIONALNE ZRÓŻNICOWANIE FIRM BIOTECHNOLOGICZNYCH}

Znając rozmieszczenie zasobów biotechnologicznych jakimi dla przemysłu biotechnologicznego są patenty, w badaniach podjęto zagadnienie regionalnego rozmieszczenia firm biotechnologicznych w wybranych krajach Unii Europejskiej ${ }^{6}$. W analizie wykorzystano dane teleadresowe serwisu szwajcarskiej firmy Biotechgate, publikowane na stronach internetowych firmy. W celu weryfikacji poprawności danych pobrane dane porównano z danymi publikowanymi przez OECD dla lat 2006-2009. W przypadku większości krajów dane dla obu źródeł były zbliżone, jednakże w przypadku Francji, Włoch lub Szwecji dane te znacznie się od siebie różniły (ryc. 14).

W celu weryfikacji liczby firm biotechnologicznych posłużono się zatem innymi źródłami m.in. opracowaniami państwowymi na temat przemysłu biotechnologicznego (np. Biotechnology Europe, French Biotech and Bio-industry Association, Biotechnology in Sweden). Z przeprowadzonych porównań we wszystkich przypadkach krajów dane związane z liczbą firm biotechnologicznych bliższe były wartościom publikowanym przez Biotechgate niż OECD. Według terminologii portalu, firmy biotechnologiczne to przedsiębiorstwa wykorzystujące żywe organizmy lub substancje biologiczne do wytwarzania produktów i usług, które mają wiele zastosowań w branżach takich jak: oczyszczanie ścieków, produkcja żywności, rolnictwo oraz farmaceutyka.

Baza danych Biotechgate wyróżnia trzy główne typy firm biotechnologicznych. Pierwszymi są firmy biotechnologiczne działające w sektorze lecznictwa i diagnostyki (Diagnostic and Therapeutic, T\&D). Ich kluczowym zadaniem jest wykorzystanie biotechnologii do odkrywania i rozwoju nowatorskich związków terapeutycznych oraz badanie związ-

${ }^{6} \mathrm{~W}$ analizie uwzględniono kraje, których liczba wszystkich firm związanych z sektorem biotechnologicznym (biotechnologiczne, farmaceutyczne, logistyczne itp.) przekraczała wg danych Biotechgate dziesięć przedsiębiorstw. 
ków pod kątem zastosowania w medycynie. Firmy te muszą posiadać swój dział badawczo-rozwojowy oraz infrastrukturę do opracowywania innowacyjnych leków. Działalność jest skupiona wokół opracowywania i rozwoju innowacyjnych związków leczniczych. Do kategorii tej nie zalicza się przedsiębiorstw, które tylko produkują lub dystrybuują leki i nie posiadają własnego działu badawczego oraz działają jedynie na polu leków generycznych, a nie opracowują innowacyjnych związków leczniczych.

\begin{tabular}{|c|c|c|c|c|c|c|c|c|}
\hline \multirow{3}{*}{ Kraj } & \multirow{2}{*}{\multicolumn{5}{|c|}{$\begin{array}{c}\text { Biotechgate } \\
\text { firmy biotechn. }\end{array}$}} & \multirow{2}{*}{\multicolumn{2}{|c|}{$\begin{array}{c}\text { OECD } \\
\text { firmy biotechn. }\end{array}$}} & \multirow{3}{*}{$\begin{array}{c}\text { róznica } \\
\text { OECD / } \\
\text { Biotechgate } \\
\langle \%\rangle\end{array}$} \\
\hline & & & & & & & & \\
\hline & R\&D & T\&D & inne & lość & $\%$ & ilosc & $\%$ & \\
\hline Francja & 220 & 79 & 59 & $358^{\circ}$ & 9,12 & 676 & 19,50 & 47,04 \\
\hline Niemcy & 542 & 139 & 136 & 817 & 20,82 & 663 & 19,13 & $-23,23$ \\
\hline Wielka Brylania & 394 & 162 & 51 & 607 & 15,46 & 487 & 14,05 & $-24,64$ \\
\hline Hiszpania & 178 & 55 & 126 & 359 & 9,15 & 399 & 11,51 & 10,03 \\
\hline Holandia & 145 & 55 & 65 & 265 & 6,75 & 206 & 5,94 & $-28,64$ \\
\hline Whochy & 250 & 65 & 237 & 552 & 14,06 & 197 & 5,68 & $-180,20$ \\
\hline Dania & 68 & 49 & 10 & 127 & 3,24 & 157 & 4.53 & 19.11 \\
\hline Belgia & 60 & 19 & 25 & 104 & 2.65 & 122 & 3.52 & 14.75 \\
\hline Austria & 48 & 26 & 12 & 86 & 2.19 & 111 & 3.20 & 22.52 \\
\hline Szwecja & 147 & 80 & 59 & 286 & 7,29 & 100 & 2,89 & $-186,00$ \\
\hline Finlandia & 31 & 13 & 12 & 56 & 1,43 & 77 & 2.22 & 27.27 \\
\hline Irlandia & 19 & 11 & 25 & 55 & 1,40 & 71 & 2,05 & 22,54 \\
\hline Republika Czeska & 30 & 0 & 13 & 43 & 1,10 & 69 & 1,99 & 37,68 \\
\hline Portugalia & 5 & 4 & 0 & 9 & 0.23 & 43 & 1,24 & 79,07 \\
\hline Polska & 32 & 3 & 25 & 60 & 1,53 & 37 & 1,07 & $-62,16$ \\
\hline Estonia & 18 & 2 & 2 & 22 & 0,56 & 31 & 0,89 & 29.03 \\
\hline Slowacja & 5 & 0 & 8 & 13 & 0.33 & 11 & 0,32 & $-18,18$ \\
\hline Slowania & 3 & 0 & 3 & 6 & 0,15 & 9 & 0,26 & 33,33 \\
\hline Cypr & 2 & 1 & 1 & 4 & 0,10 & b.d & b.d & b.d \\
\hline Grecja & 2 & 2 & 0 & 4 & 0,10 & b.d & b.d & $b, d$ \\
\hline Chorwacja & 0 & 1 & 0 & 1 & 0,03 & b.d & b.d & b.d \\
\hline Weigry & 49 & 5 & 14 & 68 & 1.73 & b.d & b.d & b.d \\
\hline Litwa & 4 & 2 & 6 & 12 & 0.31 & b.d & $b d$ & b.d \\
\hline totwa & 4 & 0 & 2 & 6 & 0,15 & b.d & $b d$ & b.d \\
\hline Rumunia & 2 & 0 & 3 & 5 & 0,13 & b.d & b.d & b.d \\
\hline Suma & 2258 & 773 & 894 & 3925 & 100 & 3466 & 100 & $x$ \\
\hline
\end{tabular}

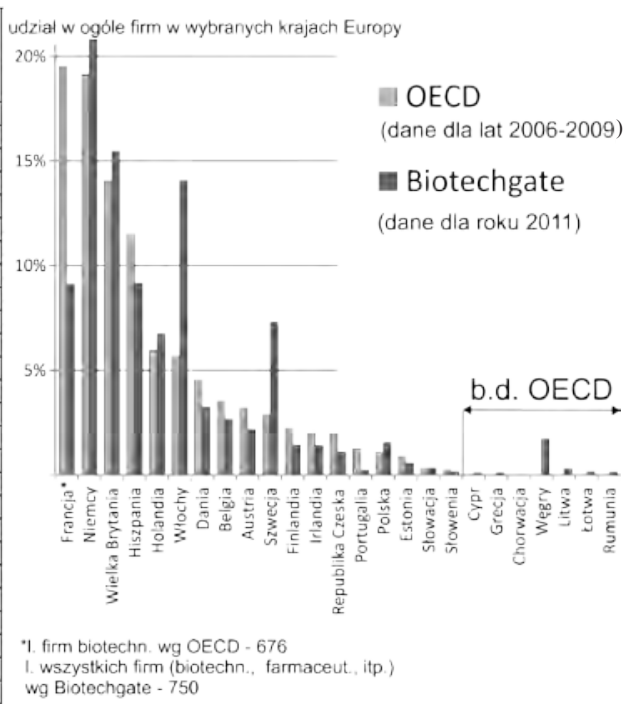

Tab. 1 i Ryc. 14. Firmy biotechnologiczne wg OECD i Biotechgate w UE w pierwszej dekadzie XXI w.

Źródło: obliczenia własne na podstawie danych Biotechgate i OECD

Drugim typem są firmy usługowe działające w sektorze rozwojowo-badawczym (R\&D). Firmy te zapewniają usługi wspomagające, takie jak: rozwój produktu, usługi analityczne, screening, produkcja, oraz usługi badawczo-rozwojowe dla przemysłu biotechnologicznego. Niektóre firmy mogą jednak prowadzić zarówno prace nad rozwojem leków, jak i prowadzić usługi. W takim przypadku decyduje główne pole działania przedsiębiorstwa. Generalnie wskaźnikiem tego rodzaju firm jest przewaga pracowników poza działem badawczym.

Ostatnim typem są firmy biotechnologiczne zaliczane do kategorii tzw. inne. Zakłady te powinny spełniać wszystkie wymagania dla firm biotechnologicznych w lecznictwie, ale nie mogą mieć związku z badaniami nad leczeniem ludzi, a powinny skupiać się m.in. na rolnictwie, kosmetykach, ochronie środowiska, technologii żywienia, biotechnologii przemysłowej, nutraceutykach lub weterynarii.

Rozmieszczenie przestrzenne firm biotechnologicznych powiela regionalny rozkład zgłoszeń patentów biotechnologicznych (ryc. 15). Według największej liczby firm biotechnologicznych wyróżniają się najsilniej uprzemysłowione i zurbanizowane (regiony stołeczne), rozwinięte gospodarczo regiony Europy Zachodniej: Lombardia, Katalonia, Londyn, 


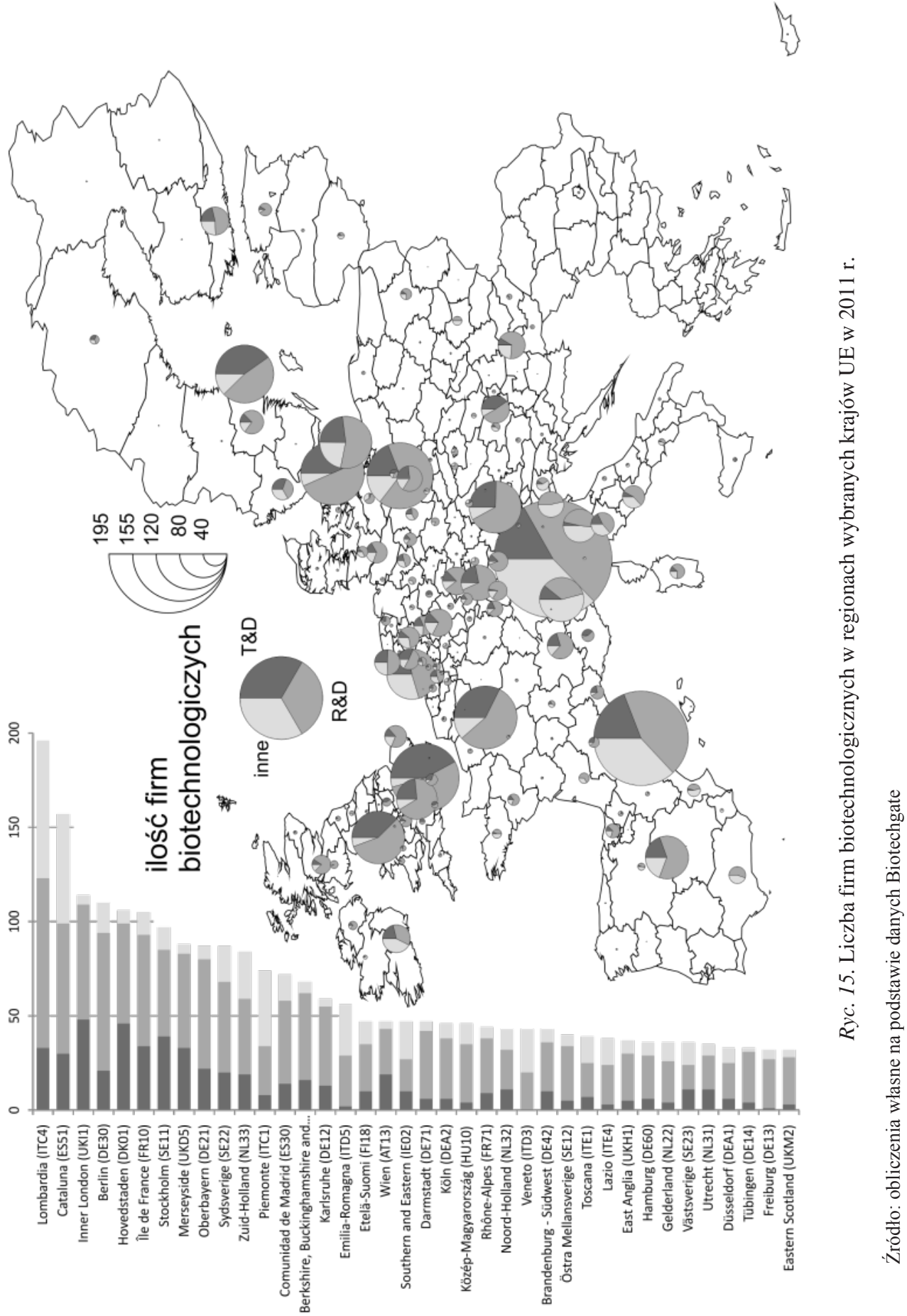



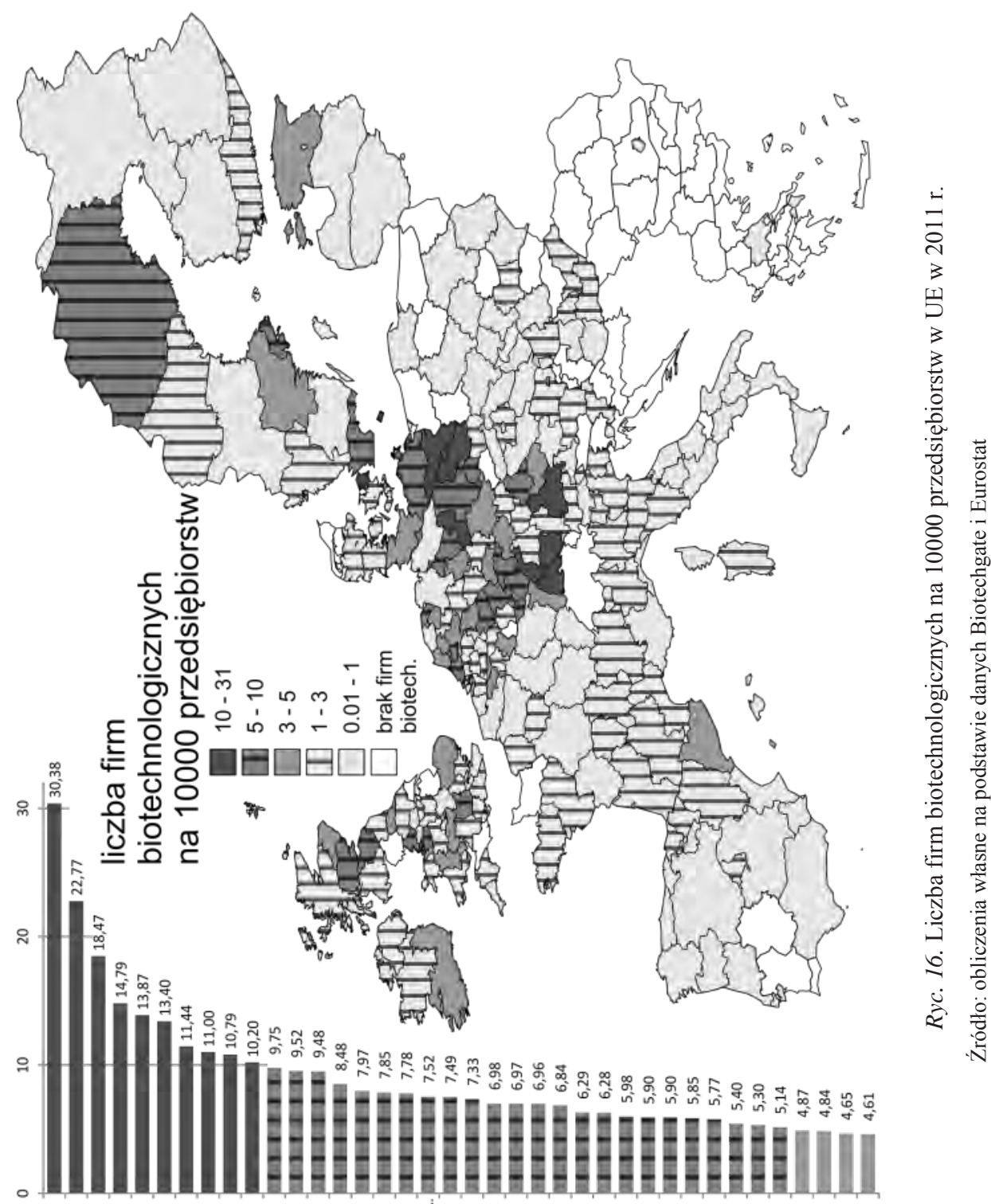

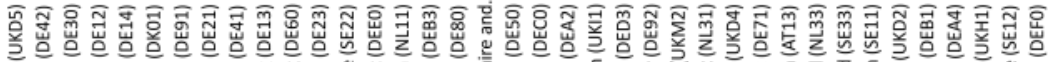

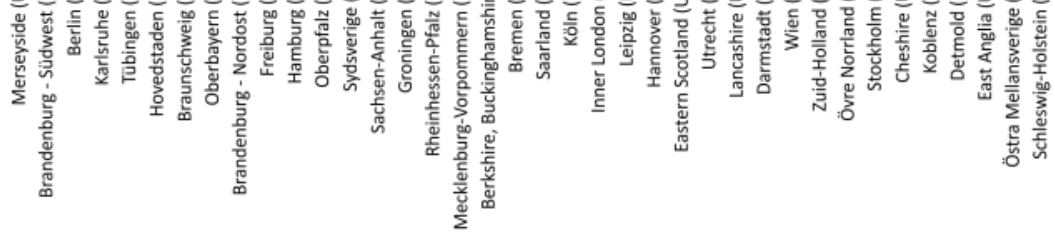


Berlin, Kopenhaga, Île-de-France, Sztokholm. Ponadto przemysł biotechnologiczny również silnie powiązany jest $\mathrm{z}$ instytucjami naukowymi i instytucjami transferu wiedzy. Przykładem może być National Research Council w Katalonii, Biotechnology Training Centre w Berlinie oraz MerseyBIO w Merseyside.

Ze względu na typ analizowanych firm biotechnologicznych można dostrzec pewien przestrzenny wzorzec ich rozmieszczenia w Europie. Największa koncentracja dotyczy firm badawczych (D\&T), które zlokalizowane są głównie w regionach stołecznych lub metropolitalnych Europy Zachodniej. Firmy usługowe (R\&D) są najbardziej rozprzestrzenione w prawie wszystkich regionach Europy, w których odnotowano występowanie firm biotechnologicznych. Natomiast firmy zaliczone do typu ,inne” skupione są w regionach na południu Europy. Sytuacja ta potwierdza znaczenie koncentracji kapitału intelektualnego i gospodarczego oraz istnienia gęstości powiązań dla rozwoju najbardziej innowacyjnych działów przemysłu, którymi w tym przypadku są firmy badawcze, posiadające najbardziej innowacyjny charakter.

W przeliczeniu liczby firm biotechnologicznych na ogólną liczbę przedsiębiorstw w regionie można zauważyć koncentrację firm biotechnologicznych w Niemczech: Brandenburgii i Bawarii. Ogólnie najwyższy udział firm biotechnologicznych wśród ogółu przedsiębiorstw posiadają pozostałe regiony Niemiec (pow. 10\%) (poza Saksonią, Hesją i Turyngią), Merseyside (30,4\%), południowa Szkocja i Londyn oraz obszar Beneluksu i Skandynawii. Również zauważalny jest południowy pas regionów o udziale firm biotechnologicznych w ogóle przedsiębiorstw regionu od 1\% do 3\%. Rozciąga się on od Kraju Basków na zachodzie wzdłuż wybrzeży Morza Śródziemnego po regiony wschodnie Węgier. Najmniejszy udział firm biotechnologicznych posiadają południowe regiony Półwyspu Iberyjskiego, Apenińskiego, regiony Europy wschodniej oraz północnej części Francji (poza Bretanią, Górną Normandią i regionem paryskim).

\section{REGIONALNE ZRÓŻNICOWANIE ROZWOJU SEKTORA BIOTECHNOLOGICZNEGO}

W związku z faktem, że w większości przypadków występuje zbieżność rozmieszczenia patentów i lokalizacji firm biotechnologicznych (ryc. 17A), przeprowadzono typologię regionów sektora biotechnologicznego dla regionów posiadających obydwa te czynniki warunkujące komercjalizację przemysłu biotechnologicznego. W analizie uwzględniono zarówno liczbę, natężenie, jak i dynamikę zmian czynników oraz typy firm biotechnologicznych.

Na podstawie analizy skupień k-średnich wyróżniono pięć typów regionów biotechnologicznych w Unii Europejskiej (ryc. 17B). Do pierwszego typu należą regiony, które posiadały zarówno dużą liczbę patentów, jak i firm biotechnologicznych. Są to regiony rozwinięte gospodarczo: Beneluksu, zachodniej Bawarii, Brandenburgii, południowo-wschodniej Anglii, południowej Skandynawii oraz francuskie regiony Île-de-France i Rodan-Alpy. W pozostałych regionach Europy zachodniej odnotowano poza dużą liczbą firm biotechnologicznych i zgłoszeń patentów biotechnologicznych, również duży wzrost patentów biotechnologicznych. Regiony peryferyjne charakteryzują się natomiast dużym wzrostem zgłoszeń patentów biotechnologicznych oraz dużą liczbą firm biotechnologicznych z sektora pozamedycznego. Zróżnicowanie regionalne Europy ze względu na rozwój sektora biotechnologicznego odzwierciedla poziom rozwoju społeczno-gospodarczego regionów Europy. 
Potwierdza to zestawienie otrzymanej struktury regionów z taksonomicznym obrazem regionalnym Europy opracowanym przez Kurka (2010) oraz Borowiec, Dorockiego i Jenner (2009).
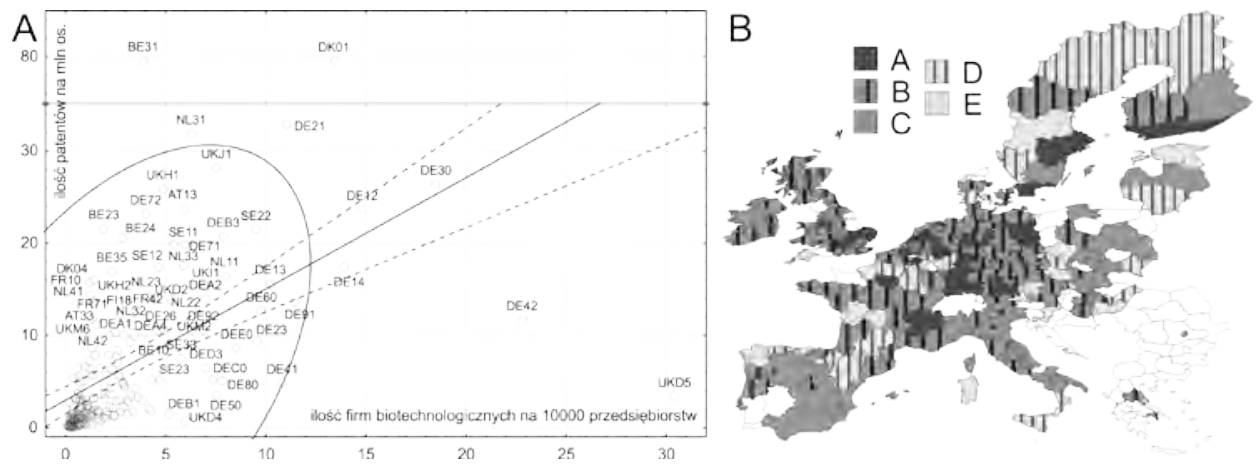

A - duża liczba patentów biotechnologicznych oraz firm biotechnologicznych

B - duża liczba patentów biotechnologicznych i firm biotechnologicznych oraz duży wzrost zgłoszeń patentów biotechnologicznych

$\mathrm{C}$ - duża liczba firm biotechnologicznych oraz duży wzrost zgłoszeń patentów biotechnologicznych

D - duży wzrost zgłoszeń patentów biotechnologicznych

E - duża liczba firm biotechnologicznych (innych) oraz duży wzrost zgłoszeń patentów biotechnologicznych kolor biały - brak firm biotechnologicznych

Ryc. 17. Zależność pomiędzy średnią ilością patentów biotechnologicznych na milion osób dla lat 2004-2008 a udziałem firm biotechnologicznych w 2011 roku (A), typologia regionów sektora biotechnologicznego w UE na podstawie analizy skupień k-średnich (B)

Źródło: obliczenia własne na podstawie danych Biotechgate i Eurostat

Jednakże, w przypadku biotechnologii można zauważyć większe zróżnicowanie rozwoju w regionach wschodnich i południowych Europy oraz większą koncentrację biotechnologii w regionach Zachodniej Europy. Potwierdza to fakt rozwoju biotechnologii nie tylko w obszarach rdzeniowych lecz również na obszarach peryferyjnych UE.

Na koniec badań nad rozwojem biotechnologii w Europie, dokonano próby odpowiedzi na pytanie: jakie czynniki wpływają na rozwój sektora biotechnologii w regionach Unii Europejskiej? W analizie posłużono się rozkładem brzegowym korelacji kanoniczej grup kilkudziesięciu zmiennych oraz przeanalizowano strukturę zależności między poszczególnymi zmiennymi. W korelacji wykorzystano m.in. standaryzowaną wielkość PKB na liczbę pracujących, udział zasobów ludzkich w nauce i technice (HRST) w poszczególnych sektorach gospodarki, udział studentów i ludności 5 i 6 poziomu edukacji ${ }^{7}$, udział pracowników B+R w poszczególnych sektorach gospodarki, nakłady w poszczególnych sektorach gospodarki, specjalizację gospodarki regionu wg struktury zatrudnienia i liczby przedsiębiorstw wg działów gospodarki oraz gęstość zaludnienia i typologię regionów ze względu na poziom urbanizacji.

Spośród wszystkich analizowanych czynników najsilniejsza współzależność $(0,89)$ występuje pomiędzy udziałem kadry naukowej $(B+R)$ a rozwojem sektora biotechnologicznego.

\footnotetext{
${ }^{7}$ Brak danych dla regionów Wielkiej Brytanii.
} 


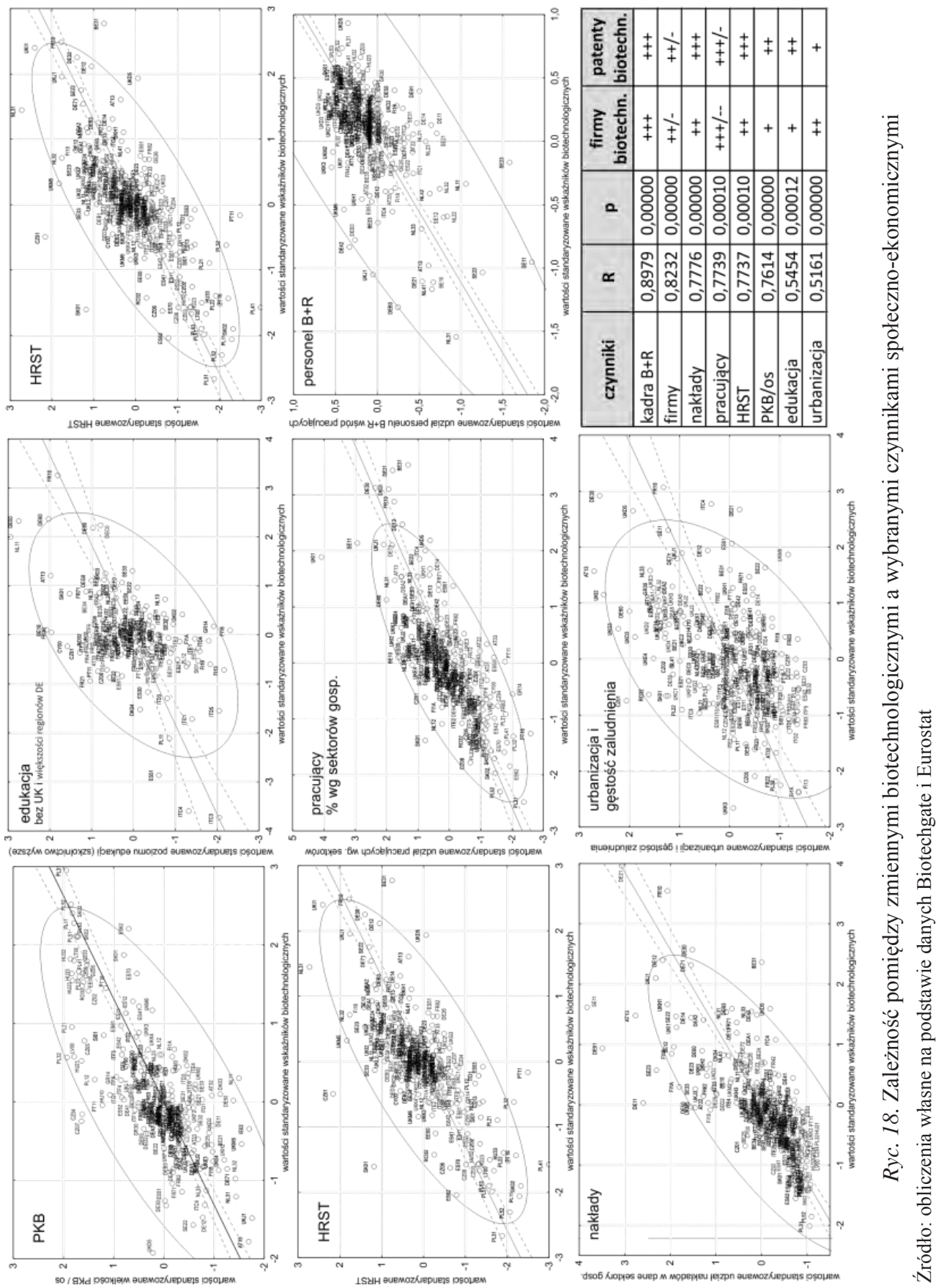


Najsilniej koreluje udział pracowników naukowych w biznesie (business enterprise sector) oraz w mniejszym stopniu udział pracowników naukowych w szkolnictwie wyższym. Następną grupą wg wielkości korelacji $(0,82)$ jest specjalizacja regionów według rodzaju przedsiębiorstw w regionie. Spośród różnych typów firm można zauważyć dodatnią współzależność pomiędzy ilością patentów a liczbą firm związanych z informacją oraz nauką, oraz ujemną z regionami związanymi z tradycyjnymi gałęziami przemysłu.

Mniejszą wartość korelacji (ok. 0,77) obserwujemy w przypadku wielkości nakładów, struktury zatrudnienia i udziału ludności HRST. Czynniki te w większym stopniu wpływają na ilość zgłoszonych patentów w regionach niż liczbę firm biotechnologicznych. Spośród poszczególnych czynników najsilniejsza współzależność z rozwojem biotechnologii występuje w przypadku wielkości nakładów w sektorze biznesu oraz szkolnictwie wyższym, udziału zatrudnianych w sektorze komunikacji i działalności naukowo-badawczej (natomiast ujemna w stosunku do zatrudnienia w rolnictwie, budownictwie i przemyśle) oraz udziału pracowników HRST z wykształceniem wyższym (core). Niewiele mniejsza współzależność $(0,76)$ występuje pomiędzy wartością PKB, a głównie liczbą firm biotechnologicznych z zakresu medycyny (D\&T). W pozostałych przypadkach tj. poziomu wykształcenia społeczeństwa i poziomu aglomeracji regionów zależność jest mała i wynosi zaledwie 0,5. Ogólnie udział zgłoszeń patentowych powiązany jest bardziej z poziomem wykształcenia ludności regionów, natomiast liczba firm biotechnologicznych bardziej zależy od poziomu urbanizacji. Tak niski wpływ poziomu wykształcenia ludności i urbanizacji wydaje się, że wynika z wąskiej specjalizacji wpływającej na jakość kapitału ludzkiego w sektorze biotechnologii oraz rozwoju biotechnologii w regionach peryferyjnych o niskiej gęstości zaludnienia i obszarach wiejskich.

\section{WNIOSKI}

$\mathrm{Na}$ zakończenie należy potwierdzić istnienie regionalnego zróżnicowania sektora biotechnologii w Europie. Rozwój sektora biotechnologicznego określonego na podstawie ilości zgłoszeń patentów biotechnologicznych i ilości firm wykazuje również pewne przestrzenne prawidłowości rozmieszczenia. W badanym okresie przełomu XX i XXI w. największy rozwój biotechnologii nastąpił początkowo w rozwiniętych gospodarczo regionach Zachodniej Europy. Natomiast współcześnie najszybszy wzrost patentów następuje w Europie Wschodniej i Południowej. Jednakże, pomimo obserwowanej tendencji do zmniejszania się międzyregionalnych różnic w rozwoju biotechnologii, w Unii Europejskiej wciąż utrzymują się duże dysproporcje w rozwoju biotechnologii, zwłaszcza pomiędzy wysoko rozwiniętymi regionami metropolitalnymi Europy Zachodniej i Europy Wschodniej. Sektor biotechnologiczny związany jest zatem głównie z dużymi ośrodkami miejskimi, skupiającymi liczne ośrodki naukowe i przemysłowe. Innym ważnym czynnikiem w rozwoju biotechnologii jest transfer wiedzy oraz instytucje i podmioty go stymulujące (np. klastry, inkubatory innowacyjności, parki naukowe). W przypadku biotechnologii, choć nie brak w niej kontrowersji związanych m.in. z procesem modyfikacji genetycznych, może się ona okazać czynnikiem determinującym stosunek społeczeństwa do nauki i innowacji ${ }^{8}$.

${ }^{8}$ Problemy z opatentowaniem genów ludzkich np. w przypadku genów BRCA1 i BRCA2 oraz wprowadzenie przez niektóre państwa (np. Niemcy, Francję, Szwajcarię) w swoich ustawach patentowych przepisów o ograniczeniu zakresu ochrony w stosunku do patentowania genów (przyp. autora). 
Rozwój nauk biotechnologicznych oraz przemysłu biotechnologicznego w największym stopniu uzależniony jest od zasobów kapitału ludzkiego tj. pracowników sektora B+R (zarówno w aspekcie nauki, jak i gospodarki) oraz od ogólnego poziomu rozwoju gospodarczego regionu. Należy zauważyć, że gospodarka regionów Europy Wschodniej w związku z uwarunkowaniami historycznymi znajduje się na innym etapie rozwoju niż regiony Europy Zachodniej.

Inną prawidłowością jest fakt, że rozwój biotechnologii ma miejsce również w obszarach dotychczas postrzeganych jako peryferyjne (np. regiony nieuprzemysłowione).

Biotechnologia w związku ze wzrostem znaczenia innowacyjności w gospodarce światowej może stać się zatem najważniejszym czynnikiem rozwoju regionalnego wielu jednostek terytorialnych m.in. Europy Wschodniej. W tym celu ważnym elementem jest budowa gęstych sieci powiązań pomiędzy instytucjami badawczymi i przemysłem przy aktywnym udziale władz i społeczeństwa.

\section{Literatura}

Aharonson B., Baum J., Plunket A., 2008, Inventive and uninventive clusters: The case of Canadian biotechnology, "Research Policy", vol. 37, Issue 6-7, Elsevier, s. 1108-1131.

Audretsch D.B., 2007, Entrepreneurship capital and economic growth, "Oxford Review of Economic Policy", vol. 23, No 1, s. 63-78.

Autant-Bernard C., Mangematin V., Massard N., 2006, Creation of Biotech SMEs in France, "Small Business Economics", 26, Springer, s. 173-187.

Barker S., Youtie J., Shapira P., 2007, Defining a Research Domain in an Emerging Technology: Vaccine Research in the State of Georgia, Working Paper, Georgia Tech Program in Science, Technology and Innovation Policy, Georgia Institute of Technology, Atlanta, USA.

Béliveau D., Haskell N., Veilleux S., 2001, Partner Selection Criteria in Emerging Markets: Theoretical Foundations and Propositions for Research in the Biotechnology Sector, "American Society of Business and Behavioral Sciences", vol. 18, No 1, s. 1048-1065.

Beuzekom (van) B., Arundel A., 2009, OECD Biotechnology Statistics 2009.

Beyond borders: Global biotechnology report 2010, http://www.ey.com/US/en/Industries/Life-Sciences/Beyond-borders_Global-biotechnology-report-2010

Biotechnology in Europe: 2006 comparative study, Critical I comparative study for EuropaBio, http:// www.bioin.or.kr/upload/stat/1216877493390.pdf (02.12.2011).

Borowiec M., 2008, Rola kapitatu ludzkiego w procesie podnoszenia konkurencyjności układów przestrzennych, [w:] Przekształcenia regionalnych struktur funkcjonalno-przestrzennych, red. D. Ilnicki, K. Janc, Rozprawy Naukowe Instytutu Geografii i Rozwoju Regionalnego Uniwersytetu Wrocławskiego 3, Instytut Geografii i Rozwoju Regionalnego Uniwersytetu Wrocławskiego, Wrocław.

Borowiec M., Dorocki S., Jenner B., 2009, Wpływ zasobów kapitału ludzkiego na ksztaltowanie spoteczeństwa informacyjnego i innowacyjności struktur przemysłowych, [w:] Funkcje przemyslu w ksztaltowaniu społeczeństwa informacyjnego, red. Z. Zioło i T. Rachwał, Prace Komisji Geografii Przemysłu Polskiego Towarzystwa Geograficznego, nr 13, Komisja Geografii Przemysłu PTG i Instytut Geografii Uniwersytetu Pedagogicznego w Krakowie, WarszawaKraków, s. 95-109.

Casper S., 2007, How do technology clusters emerge and become sustainable?: Social network formation and inter-firm mobility within the San Diego biotechnology cluster, "Research Policy", vol. 36, Issue 4, s. 438-455. 
Casper S., 2009, The Marketplace for Ideas: Can Los Angeles Build a Successful Biotechnology Cluster? A Report to the John Randolph Haynes Foundation, Keck Graduate Institute of Applied Life Sciences.

Casper S., Murray F., 2005, Careers and Clusters: Analyzing the Career Network Dynamic of Biotechnology Clusters, "Journal of Engineering and Technology Management", vol. 22, Issue 1, s. $21-74$, http://ssrn.com/abstract $=1503885$

Chmiel A., 1991, Biotechnologia. Podstawy mikrobiologiczne i biochemiczne, Państwowe Wydawnictwo Naukowe, Warszawa.

Cooke P., 2003, The Regional Development Agency in the Knowledge Economy: Boundary Crossing for Innovation Systems, European Regional Science Association Annual Conference - "Peripheries, Centres, and Spatial Development in the New Europe", http://www-sre.wu-wien.ac.at/ersa/ersaconfs/ersa03/cdrom/ papers/452.pdf (02.12.2011).

Cooke P., De Laurentis C., 2002, The Index of Knowledge Economies in the European Union: Performance Rankings of Cities and Regions, Regional Industrial Research Report 41, Centre for Advanced Studies, Cardiff University.

Corolleur F., Mangematin V., Torre A., 2003, French Biotech Start Ups and Biotech Clusters in France: The Importance of Geographic Proximity, [w:] Biotechnology in Comparative Perspective Growth and Regional Concentration, red. G. Fuchs, B. Luib, London: Routledge, s. 221-257.

Czyż T., Chojnicki Z., 2008, Gospodarka oparta na wiedzy w regionach metropolitalnych i aglomeracjach miejskich w Polsce, Studia KPZK PAN, 120, Komitet Przestrzennego Zagospodarowania Kraju PAN, Warszawa, s. 74-95.

Dahl M.S., Sorenson O., 2007, Home sweet home: Social capital and location choice, Social Science, s. 1-22, www.druid.dk (02.12.2011).

Delerue H., Lejeune A., 2008, Internationalization of biotechnology start-ups: the role of geographical location,http://uqam.academia.edu/ALejeune/Papers/456543/Internationalization_of_Biotechnology_Start-ps_the_Role_of_Geographical_Location (02.12.2011).

Domański B., 2000, Some aspects of the development of Polish manufacturing in the perspective of knowledge-based economy, [w:] A. Kukliński (red.), The knowledge-based economy. The European challenges of the 21st century, State Committee for Scientific Research, Warszawa, s. 281-287.

Europabio 2011, http://www.europabio.org/what-biotechnology (05.12.2011).

Goldberg I., Goddard G., Kuriakose S., 2008, Building Knowledge-Based Economy and Absorptive Capacity to Enhance Growth: The Role of Cross-Border Knowledge Flows in Europe and Central Asia (ECA), [w:] Knowledge-Based Economy as Factor of Competitiveness and Economy Growth, ed. M. Runiewicz-Wardyn, L. Koźmiński, Academy of Entrepreneurship and Management, Warszawa.

History of Modern Biotechnology I, "Advances in Biochemical Engineering Biotechnology”, vol. 69, A. Fiechter (Editor, Contributor).

Innovation in the Baltic Sea Region, Final Report to the European Commission, Directorate-General Regional Policy, 2011, Sweden, http://www.interact-eu.net/mint/pepper/orderedlist/downloads/ download.php?file=http $\% 3 \mathrm{~A} / / \mathrm{www}$.interact-eu.net/downloads/4445/Study_Innovation_in_ EUSBSR_07.2011.pdf (02.12.2011).

Kelly M., 2004, Biotech Clusters in Europe - Biotech Clusters get a Shot in the Arm, http://www.woods-bagot.com/en/Documents/Public_Research/04_biocluster_Europe_M_Kelly.pdf (02.12.2011).

Klasik A., 2009, Kreatywne miasta i aglomeracje, studia przypadków, Wydawn. Akad. Ekonomicznej im. Karola Adamieckiego w Katowicach.

Kurek S., 2010, Przestrzenne zróżnicowanie poziomu rozwoju regionalnego w Unii Europejskiej w świetle wybranych mierników, [w:] Z. Zioło i T. Rachwał (red.), Procesy przemian przemystu $i$ ustug $w$ wybranych krajach, Prace Komisji Geografii Przemysłu Polskiego Towarzystwa 
Geograficznego, nr 16, Komisja Geografii Przemysłu PTG i Instytut Geografii Uniwersytetu Pedagogicznego w Krakowie, Warszawa-Kraków, s. 87-104.

Lecocq C., Leten B., Kusters J., Van Looy B., 2010, Do Firms Benefit from Being Present in Multiple Technology Clusters? An Assessment of the Technological Performance of Biopharmaceutical Firms, Section of Economic Geography, series Papers in Evolutionary Economic Geography (PEEG), No 10.19, Utrecht University.

Life Sciences and Biotechnology - A Strategy for Europe, 2002, Communication from the Commission to the Council, the European Parliament, the Economic and Social Committee and the Committee of the Regions, Commission of the European Communities, http://ec.europa.eu/biotechnology/ pdf/com2002-27_en.pdf (02.12.2011).

Markowski T., 2008, Gospodarka bazująca na wiedzy (GOW) a wyzwania wobec zagospodarowania przestrzennego - konceptualizacja problemu, [w:] T. Marszał (red.), Rola polskich aglomeracji wobec wyzwań Strategii Lizbońskiej, „Studia”, t. CXX, tom wydany z okazji jubileuszu 50-lecia KPZK PAN, Komitet Przestrzennego Zagospodarowania Kraju Polska Akademia Nauk, Warszawa.

Rachwał T., Wiedermann K., Kilar W., 2009, Rola przemystu w gospodarce układów regionalnych Unii Europejskiej, [w:] Z. Zioło i T. Rachwał (red.), Problemy kształtowania się przestrzennych struktur przemystowych i ich otoczenia, Prace Komisji Geografii Przemysłu Polskiego Towarzystwa Geograficznego, nr 14, Komisja Geografii Przemysłu PTG i Instytut Geografii Uniwersytetu Pedagogicznego w Krakowie, Warszawa-Kraków, s. 31-42.

Saxenian A., 1999, Silicon Valley's New Immigrant Entrepreneurs, Public Policy Institute of California, San Francisco.

Saxenian A., Motoyama Y., Xiaohong Q., 2003, Local and Global Networks of Immigrant Professionals in Silicon Valley, Public Policy Institute of California, San Francisco.

Science, technology and innovation in Europe. 2011 edition, Office of the European Union, European Union, 2011.

Shachmurove Y., Shachmurove A., 2004, Choosing Between Promising and Crowded Industries: How Does the Venture Capital Industry Fare in Each? PIER Working Paper No. 04-044, http://ssrn. com/abstract $=637222(02.12 .2011)$.

Shachmurove Y., 2004, The Reality of IPO Performance: An Empirical Study of Venture-Backed Public Companies, PIER Working Paper No. 04-030, http://ssrn.com/abstract=568165 (02.12.2011).

Stryjakiewicz T., 2008, Sektor kreatywny jako czynnik ksztaltujący nowa jakość przestrzeni europejskiej, [w:] Przekształcenia Regionalnych Struktur Funkcjonalno-Przestrzennych „Europa bez granicnowe wyzwania”, red. D. Ilnicki, K. Janc, Rozprawy Naukowe Instytutu Geografii i Rozwoju Regionalnego Uniwersytetu Wrocławskiego 3, Instytut Geografii i Rozwoju Uniwersytetu Wrocławskiego, Wrocław, s. 11-18.

Stuart T., Sorenson O., 2003, The geography of opportunity: spatial heterogeneity in founding rates and the performance of biotechnology firms, "Research Policy", vol. 32, s. 229-253.

Sytch, M., Bubenzer P., 2008, Research on Strategic Alliances in Biotechnology: An Assessment and Review, [w:] Handbook of Bioentrepreneurship, red. H. Patzelt, T. Brenner, Springer, New York, s. $105-131$.

Szabó P., 2008, The Pentagon and Other Geometrical Figures of Europe's Economic Core, "Romanian Review of Regional Studies", vol. IV, No 2, Centre For Regional Geography, Presa Universitară Clujeană, s. 11-20.

The Bioeconomy to 2030: Designing a Policy Agenda, OECD 2009.

Van Overwalle G., 2010, Policy Levers Tailoring Patent Law to Biotechnology. Comparing US and European Approaches, University of California, "Irvine Law Review", vol. 1, Issue 2, s. 443 514, http://www.law.uci.edu/lawreview/index.html (04.12.2011). 
Wasiak M., 2007, Gospodarka oparta na wiedzy w rankingu "Knowledge Economy Index" $i$ "Knowledge Index" Banku Światowego (wg Knowledge Assessment Methodology 2008). Pozycja Polski na tle nowych krajów czlonkowskich Unii Europejskiej (Central and Eastern Europe-CEE), Świętokrzyskie Centrum Edukacji na Odległość, Zeszyty Naukowe 8, http://www. sceno.edu.pl/ (03.12.2011).

Wolf H., Michelsen C., Schwartz M., 2010, Regional Entrepreneurial Opportunities in the Biotech Industry. Exploring the Transition from Award-winning-ascent Entrepreneurs to Real Start-ups, IWH Discussion Papers, No 25.

Zucker L.G., Darby M.R., Armstrong J., 1989, Geographically localized knowledge: spillovers or markets?, "Economic Inquiry", vol. XXXVI, s. 65-86.

\section{Regional differences in the development of biotechnology in Europe}

Modern biotechnology is widely regarded as information technology, a new wave of knowledgebased economy. It is one of the key technologies of the 20th century, with potentially a versatile range of applications, such as healthcare, agriculture and industrial processes. Simultaneously, biotechnology and pharmacy are the strongest fields in the currently funded basic research which contributes to progress in other sciences.

According to the European Parliament's report "Life sciences and biotechnology - A Strategy for Europe", it is taken for granted that modern biotechnology offers unique opportunities of satisfying many human needs. Biotechnology could thus serve the European Union as a great contribution to the achievement of its policy objectives of economic growth and job creation, public health, environmental protection and sustainable development.

In the following years, life sciences and biotechnology industry could potentially become the major areas of science, industry and employment and could improve the quality of life through innovative medical applications, upgrading of industrial bases of Europe, and better environment.

This article aims at presenting regional differences in the development of biotechnology in Europe. Delimitation of regions will take place both on the basis of academic achievement in the field and the location of the biotechnology industry in Europe. An attempt will also be made to link the development of biotechnology with other markers of socio-economic regions of Europe.

Dr Sławomir Dorocki

Uniwersytet Pedagogiczny w Krakowie

Instytut Geografii

Zakład Przedsiębiorczości i Gospodarki Przestrzennej

e-mail: sdorocki@up.krakow.pl

Dr Jan Paweł Jastrzębski

Uniwersytet Warmińsko-Mazurski w Olsztynie

Katedra Fizjologii i Biotechnologii Roślin

e-mail: jan.jastrzebski@uwm.edu.pl 